Discussion Paper No. 13-093

\title{
Job Machine, Think Tank, or Both - What Makes Corporate Spinoffs Different?
}

Helmut Fryges, Bettina Müller, and Michaela Niefert

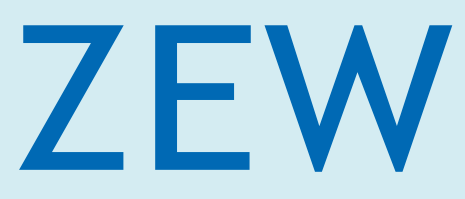

Zentrum für Europäische Wirtschaftsforschung $\mathrm{GmbH}$ Centre for European Economic Research 
Discussion Paper No. 13-093

\title{
Job Machine, Think Tank, or Both - What Makes Corporate Spinoffs Different?
}

\author{
Helmut Fryges, Bettina Müller, \\ and Michaela Niefert
}

Download this ZEW Discussion Paper from our ftp server:

http://ftp.zew.de/pub/zew-docs/dp/dp13093.pdf

Die Discussion Papers dienen einer möglichst schnellen Verbreitung von neueren Forschungsarbeiten des ZEW. Die Beiträge liegen in alleiniger Verantwortung der Autoren und stellen nicht notwendigerweise die Meinung des ZEW dar.

Discussion Papers are intended to make results of ZEW research promptly available to other economists in order to encourage discussion and suggestions for revisions. The authors are solely responsible for the contents which do not necessarily represent the opinion of the ZEW. 


\section{Non-Technical Summary}

Start-ups are a vehicle to transfer knowledge and technology within an economy. The way in which this occurs is that founders of start-ups pick up ideas that otherwise would have been neglected and bring them to the market. A group of start-ups which are especially apt to spread knowledge and technology are start-ups by previous employees of incumbent firms, usually called corporate spinoffs. The founders of these start-ups are assumed to transfer intellectual assets encountered during their employment. In this paper, we examine whether the transfer of ideas and skills from incumbent firms affects the employment growth and post-entry innovation activities of new firms.

A key contribution of our paper is that we apply a definition of corporate spinoff which directly draws on the notion of knowledge and technology transfer. The data set we use is the KfW/ZEW Start-Up Panel. It has explicit information on the importance of new ideas and skills that the founders developed during employment for setting up the firm. We classify a start-up as corporate spinoff if a new idea that emerged from the founders' work for an incumbent firm has been essential for establishing the new firm. We apply propensity score matching in order to determine whether this idea is causally related to the employment growth and innovation activities of the corporate spinoff. As control group we use start-ups by previous employees for which such an idea has not been essential. We also analyse whether an idea that was at least of great importance and skills that were essential for establishing the firm affect these outcome indicators.

Our findings indicate that the transfer of an essential idea leads to higher post-entry innovation activities but not to higher employment growth. Start-ups that are based on an idea of at least great importance benefit from the idea both in terms of innovation activities and employment growth. However, essential skills have hardly any effect on these indicators. We conclude that a transferred idea is primarily an input factor and a stimulus for subsequent innovation activities of start-ups. In addition, our results show that it is important to carefully differentiate between varying types of knowledge and technology transfer. Start-ups do not benefit from all types to the same degree. With respect to innovation activities it is rather ideas that matter than skills. 


\section{Das Wichtigste in Kürze}

Gründungen können als Vehikel des Wissens- und Technologietransfers angesehen werden. Dies geschieht in der Weise, dass Gründer Ideen kommerzialisieren, die sonst vernachlässigt worden wären. Eine Gruppe von Gründungen, die besonders geeignet ist, Wissen und Technologien zu verbreiten, sind Gründungen von ehemaligen Beschäftigten etablierter Unternehmen. Sie werden gewöhnlich als Corporate Spinoffs bezeichnet. In diesem Papier untersuchen wir, ob der Transfer von Ideen und Fähigkeiten aus bestehenden Unternehmen das Beschäftigungswachstum und die Innovationsaktivitäten neuer Unternehmen beeinflusst.

Ein wichtiger Beitrag unseres Papiers ist, eine Definition von Corporate Spinoffs zu verwenden, die direkt auf den Wissens-und Technologietransfers abzielt. Das für die Untersuchung verwendete KfW/ZEW-Gründungspanel enthält explizite Informationen zur Bedeutung von Ideen und Fähigkeiten, welche die Gründer in ihrer vorherigen Beschäftigung entwickelt haben, für die Gründung des Unternehmens. Wir klassifizieren eine Gründung als Corporate Spin-off, wenn eine neue Idee, die während der Arbeit der Gründer für ein etabliertes Unternehmen entstanden ist, unverzichtbar für die Gründung war. Wir verwenden das Propensity Score Matching-Verfahren, um festzustellen, ob diese Idee kausal mit dem Beschäftigungswachstum und den Innovationsaktivitäten von Corporate Spinoffs zusammenhängt. Als Kontrollgruppe dienen Gründungen von ehemaligen Beschäftigten, für die eine solche Idee nicht unverzichtbar war. Außerdem untersuchen wir, ob eine Idee, die zumindest von großer Bedeutung war, und Fähigkeiten, die unverzichtbar für die Gründung waren, einen kausalen Effekt auf die Ergebnisvariablen haben.

Unsere Ergebnisse zeigen, dass der Transfer einer unverzichtbaren Idee zu höheren Innovationsaktivitäten, aber nicht zu mehr Beschäftigungswachstum führt. Gründungen, die auf einer Idee von mindestens großer Bedeutung basieren, profitieren von der Idee sowohl in Bezug auf Innovationsaktivitäten als auch auf Beschäftigungswachstum. Unverzichtbare Fähigkeiten haben jedoch kaum Einfluss auf die Ergebnisvariablen. Wir schließen daraus, dass eine transferierte Idee in erster Linie ein Inputfaktor und ein Impuls für nachfolgende Innovationsaktivitäten von Gründungen ist. Außerdem zeigen die Ergebnisse, dass es wichtig ist, sorgfältig zwischen den unterschiedlichen Arten des Wissens- und Technologietransfers zu unterscheiden. Gründungen profitieren nicht von allen Arten gleichermaßen. Im Hinblick auf Innovationsaktivitäten sind es eher Ideen, die zählen, als Fähigkeiten. 


\title{
Job Machine, Think Tank, or Both - What Makes Corporate Spinoffs Different?
}

\author{
Helmut Fryges*, Bettina Müller**, and Michaela Niefert***
}

\begin{abstract}
One way through which knowledge and technology transfer can take place is through the foundation of new firms by former employees of incumbent private firms. In this paper, we examine whether knowledge transferred from the incumbent causally affect employment growth and postentry innovation activities of the new firm. We focus on start-ups for which a new idea (a new product, technology, production process or management concept), which the founder developed during her work as an employee, was essential for setting up the new business. These firms are denoted corporate spinoffs. Using data from German start-ups founded in the period from 2005 to 2008, we apply nearest neighbour propensity score matching. We find that corporate spinoffs outperform other start-ups founded by former employees of incumbent private firms that are not based on an essential idea in terms of post-entry innovation activities. However, we cannot show that corporate spinoffs benefit from the transferred idea in terms of employment growth. We conclude that a transferred idea is primarily an input factor and a stimulus for subsequent post-entry innovation activities of corporate spinoffs.
\end{abstract}

Keywords: knowledge and technology transfer, corporate spinoffs, propensity score matching, KfW/ZEW Start-Up Panel

JEL-Classification: $L 26, L 25, O 31, C 21$

\footnotetext{
Acknowledgements: Valuable comments and suggestions of two anonymous referees are gratefully acknowledged. A previous version of this paper was presented at the ZEW Workshop on Spin-Off Entrepreneurship 2011 in Mannheim and 42 ${ }^{\text {nd }}$ Australian Conference of Economists 2013 in Perth. We thank participants for their helpful remarks. Further, we thank Christian Rammer for useful suggestions and Sarah Gatenby-Clark for careful proof reading. All remaining errors are our sole responsibility.

* Australian Innovation Research Centre, University of Tasmania, 1 College Road, Sandy Bay TAS 7005, Australia, helmut.fryges@utas.edu.au.

** Centre for European Economic Research (ZEW), Research Department Industrial Economics and International Management, P.O. Box 103443, 68034 Mannheim, Germany, bettina.mueller@zew.de.

*** Centre for European Economic Research (ZEW), Research Department Industrial Economics and International Management, P.O. Box 103443, 68034 Mannheim, Germany, niefert@zew.de.
} 


\section{Motivation}

One of the expectations connected with start-ups is that they contribute to the knowledge and technology transfer within an economy. This transfer in turn is expected to make an economy more competitive by increasing the quantity and quality of innovation which then leads to sustainable jobs. From this perspective, corporate spinoffs have received considerable attention in the literature. Spinoff founders are assumed to transfer intellectual assets encountered as an employee of an incumbent firm to the spinoff firm (Agarwal et al., 2004; Franco and Filson, 2006). If corporate spinoffs play an important role in knowledge and technology transfer, they should be particularly qualified for meeting the expectations and create both jobs and innovations.

In this paper, we examine whether knowledge transferred from the incumbent firm causally affects employment growth and post-entry innovation activities of corporate spinoffs. A key contribution of our paper is to use a definition of corporate spinoffs which directly draws on the notion of knowledge and technology transfer. We use the KfW/ZEW Start-Up Panel, a unique data set on German start-ups that comprises explicit information on whether a new idea that the founder developed as an employee in a private company has been essential for setting up the firm. This allows us to define corporate spinoffs by the transfer of a new idea and distinguishes our paper from related studies that define spinoffs as start-ups whose founders were previously employed in the same industry (e.g. Klepper 2001; Franco and Filson, 2006).

Previous studies on corporate spinoff performance have analysed, to the best of our knowledge, only survival. Although survival must be all firms' first and foremost objective, other measures of firm outcome concern researchers and policy makers too. Most of all, start-ups and young firms are expected to create new jobs. Whether corporate spinoffs outperform other start-ups in terms of employment growth and insofar can be considered as 'job machines' is still an open research question. Furthermore, innovation activities of start-ups are of primary interest because innovative start-ups were shown to be an integral part of an economy's innovation system (Aghion et al., 2006; Acs and Audretsch, 1990). Start-ups' and young firms' innovative contribution is not restricted to those products and services the start-up commercialises at market entry but also comprises recurrent post-entry innovation activities (Arvanitis and Stucki, 2010). Whether corporate spinoffs are 'think tanks' in the sense that they are entities with enduring superior research and innovation activities compared to other start-ups, is likewise not yet answered and is addressed by our paper. Our main finding is that a transfer of new ideas increases innovation activities after start-up but does not enhance corporate spinoffs' employment growth. 
The paper proceeds as follows: In section 2, we summarise the relevant theoretical and empirical findings on corporate spinoffs. In section 3, we describe our data set and our strategy of identifying corporate spinoffs. In section 4, descriptive results are shown for corporate spinoffs in comparison with other start-ups. The estimation method is explained in section 5. Section 6 discusses the results and section 7 concludes.

\section{Previous Research}

The influence the transfer of intangible assets has on the formation and the subsequent development of new firms has been studied intensively in previous literature. Transferred intangible assets may originate from various sources like universities, public research institutes, public companies or private companies. Start-ups that are based on research from academic institutions, usually denoted as academic spinoffs or university spinoffs, and the role the transferred intangible assets play for the academic spinoffs' employment growth and innovation activities have been investigated by an increasing number of studies (see Djokovic and Souitaris, 2008, or O’Shea et al., 2008, for an overview and Lejpras and Stephan, 2011, for an example of a study on academic spinoffs' innovation activities). Corporate spinoffs are typically defined to be start-ups whose founders previously worked as employees for an incumbent firm in the same industry (Garvin, 1983; Klepper 2001, 2002; Agarwal et al. 2004, Klepper and Sleeper, 2005; Franco and Filson, 2006; Buenstorf, 2007; Cabral and Wang, 2009). Sometimes the terms 'spin-outs' (Agarwal et al., 2004; Franco and Filson, 2006), 'employee spinoffs' (Muendler et al., 2012) or 'entrepreneurial spinoffs' (Helfat and Lieberman, 2002) are used to distinguish corporate spinoffs from entrants in an industry which are founded by established firms and which are often controlled by the parent firm. The latter are called 'divestitures' or 'parent spinoffs' (Muendler et al., 2012; Helfat and Lieberman, 2002). Similar to academic spinoffs, it is assumed that the founders of corporate spinoffs use knowledge, skills and ideas they encountered during their time as employees thereby transferring knowledge and technology from one economic unit to another (Agarwal et al., 2004; Franco and Filson, 2006).

Corporate spinoffs (referred to as 'spinoffs' below for convenience) have been found to play a major role in the development of certain industries such as semiconductors (Braun and MacDonald, 1978), disk drives (Franco and Filson, 2006), lasers (Buenstorf, 2007; Klepper and Sleeper, 2005) and automobiles (Klepper, 2002). Several arguments have been put forward to explain the emergence of spinoffs. First, problems in designing incentive-compatible contracts prevent discoveries made by employees being commercialised in an incumbent firm (Wiggins, 1995; Anton and Yao, 1995). Second, employees become frustrated at their workplaces. This frustration can arise when firms do not develop both their technological and market pioneering know-how so that employees get the impression that opportunities are neglected (Agarwal et al., 2004), ideas of employees are not sufficiently recognised, the management practices with respect to the organisation or the methods of rewarding employees are perceived to be poor or employees disagree with the strategic direction of their employ- 
er (Garvin, 1983; Klepper and Thompson, 2010). Third, employees want to exploit knowledge that they encountered during their work in an established firm. Incumbent firms normally do not exploit all arising opportunities because, for example, they fear cannibalising effects on their current activities (Agarwal et al., 2004) or losing customers as a result of new products or services not matching the preferences of the current clients (Christensen, 1993). Sometimes incumbent firms also do not recognise an opportunity but an employee does (Klepper and Sleeper, 2005). Fourth, spinoffs are the result of a reorganisation or a crisis of the incubator firm. For instance, a firm is taken over by a firm from another industry, a new CEO is hired from outside the firm, or the growth rates of the firm slow down (Brittain and Freeman, 1986). And fifth, employees feel that they would make good entrepreneurs (Cabral and Wang, 2009).

With the exception of the last two explanations, all explanations are based on the notion that spinoffs involve some sort of innovation and come along with knowledge and technology transfer between firms. However, this notion is not directly reflected in the prevalent definition and operationalisation of spinoffs in the literature. The mere fact that founders worked for an incumbent firm in the same industry does not necessarily imply a transfer of knowledge and technologies. It is possible that the founders developed a business idea that does not originate from their former employment and that they make only little use of the knowledge they encountered there. Furthermore, the definition is imprecise insofar as it leaves open what is exactly meant by 'the same industry'. Classification of sectors is always arbitrary to some extent. Consequently, empirical studies report very different results regarding the quantitative importance of spinoffs. For example, reported shares of spinoffs in all start-ups vary between 45 and 71\% for the US (Cooper, 1985; Bureau of the Census, 1997; Bhidé, 2000). The definition also misses out many ‘vertical’ spinoffs (Muendler et al., 2012) which occur across industries.

Alternative spinoff definitions require that a substantial share of a spinoff's employees (25\% or 50\%, depending on the definition used) come from the same workplace (which does not have to belong to the same industry as the start-up) (Muendler et al., 2012; Eriksson and Kuhn, 2006). Although employee flows do not necessarily imply a transfer of intellectual assets, the volume of transfer tends to be larger the more employees have moved from the former workplace.

The transfer between the incubator firm and the spinoff encompass a variety of assets. These include technologies (Garvin, 1983; Klepper and Sleeper, 2005; Muendler et al., 2012), knowledge about technologies (Helfat and Lieberman, 2002; Agarwal et al., 2004), ideas (Agarwal et al., 2004; Klepper and Sleeper, 2005), market specific knowledge (knowledge about consumer needs, industry conditions, country or regional conditions; Helfat and Lieberman, 2002; Agarwal et al., 2004; Rauch and Watson, 2004; Klepper and Sleeper, 2005), management expertise (Agarwal et al, 2004; Gompers et al, 2005), communication practices (Phillips, 2002), rules, routines, procedures (Agarwal et al., 2004; Muendler et al., 2012), personal networks (Helfat and Lieberman, 2002; Eriksson and Kuhn, 2006), 
skilled labour (Garvin, 1983), financial capital (Helfat and Lieberman, 2002), and patents, trademarks, brand names and designs (Garvin, 1983; Helfat and Lieberman, 2002).

If actually transferred, these assets can affect the development of spinoffs. Many authors have argued that spinoffs can be expected to benefit from this transfer in terms of performance (Klepper, 2002; Agarwal et al., 2004; Buenstorf, 2007; Cabral and Wang, 2009; Eriksson and Kuhn, 2006). A common finding is that spinoffs outperform other start-ups in terms of survival (Sleeper, 1998; Phillips, 2002; Agarwal et al., 2004; Eriksson and Kuhn, 2006; Dahl and Reichstein, 2007; Buenstorf, 2007; Muendler et al., 2012). However, it is not clear from this literature whether the higher survival rates of spinoffs are the result of a knowledge and technology transfer because the applied definition of spinoffs does not reflect whether such transfer actually took place.

In this paper, we define a start-up to be a corporate spinoff if a new idea that the founder developed during employment in a private company has been essential for setting up the firm. Our perception of a new idea refers to new products, new technologies, new production processes or new management concepts. The approach of identifying corporate spinoffs in our data is related to the procedure used by Egeln et al. (2003) and Egeln et al. (2009) to identify academic spinoffs in Germany and Austria. It has been proven to reliably single out start-ups which come along with a substantial knowledge and technology transfer from academic institutions from all start-ups established in knowledge and technology intensive sectors.

Applying nearest neighbour propensity score matching, we examine whether knowledge or technology transferred from an established firm to a corporate spinoff affects employment growth and post-entry innovation activities of spinoffs. Technically speaking, we are interested in the Average Treatment Effect of the Treated (ATT) with 'spinoff' (i.e. having received knowledge or technology transfer from an established firm) as treatment.

\section{Data and identification of corporate spinoffs}

\subsection{Data set}

We use data from the first three survey waves of the KfW/ZEW Start-Up Panel (KfW/ZEWGründungspanel), a unique panel data set on newly founded firms in Germany. This data set was established in 2008 by the Centre for European Economic Research (ZEW), KfW Bankengruppe (Germany's largest state owned promotional bank) and Creditreform (Germany's largest credit rating agency) in order to analyse the development of start-ups over time. The data is collected once a year using Computer-Aided Telephone Interviews (CATI). The target size of the survey totals to an average of 6,000 interviews per year.

The statistical unit of the KfW/ZEW Start-Up Panel is the legally independent firm. De-mergers and subsidiaries are excluded from the survey. The sample is stratified by three criteria: (i) year of firm 
formation, (ii) industry (10 sectors as defined in Table 12 in the appendix), and (iii) whether or not the firm has received financial support by KfW. Each year, a random sample of firms is drawn which have been founded during the three years prior to the year of the survey. Firms that have participated in the survey are contacted in subsequent years as long as they are not older than eight years. One half of the firms included in the sample operate in high-technology industries. ${ }^{1}$

Firms that participate in the survey for the first time are asked to answer a baseline questionnaire on characteristics of firm founders (e.g. age, gender, education) and on structural properties of firms at the time of start-up. ${ }^{2}$ Firms that already participated in previous waves answer a follow-up questionnaire that focuses on changes over time, e.g., changes in the number of employees or in long-term innovation behaviour. Besides information collected every year, a focus theme is included into each year's follow-up questionnaire. In the third survey wave conducted in 2010, there was a special topic on corporate spinoffs. 4,103 firms founded between 2005 and 2008 participated in the 2010 follow-up survey.

\subsection{Identification of corporate spinoffs}

In order to identify spinoffs, firms were first asked whether at least one of the founders worked as a dependent employee in a private company. Previous employment in a private company is the necessary condition for a start-up to be classified as a spinoff. All start-ups with at least one founder previously working for a private company were then asked about the importance of two different measures of knowledge transfer for the establishment of the new firm: (i) specific skills that the founder has acquired during her work for the private company; (ii) new ideas that emerged from the founder's work for the private company. The interviewees had to assess whether the new ideas or the acquired specific skills were 'essential', 'of great importance', 'of minor importance' or 'of no importance' for the formation of their own firm. In case of a team foundation, interviewees had to assess the importance of new ideas and specific skills of any of the founders. ${ }^{3}$

86\% of the firms participating in the 2010 follow-up survey have been established by at least one founder previously employed by a private company, which corresponds to 3,504 observations. Using population weights that correct for the stratification design of the KfW/ZEW Start-Up Panel we find that $84 \%$ of all start-ups founded in the period from 2005 to 2008 fall into this group. Firms in which none of the founders previously worked for a private company include firms that have been set up, for instance, by civil servants or other employees of public organisations, homemakers, and students or graduates from universities that started their own business immediately after graduation.

\footnotetext{
${ }^{1}$ For a detailed description of the survey design see Fryges et al. (2010).

${ }^{2}$ Interviews are preferably conducted with one of the founders of the firm. If the founders are no longer active, a member of management that is also owner of the firm is interviewed.

${ }^{3}$ The wording of the questions used to identify spinoffs is documented in Table 13 in the appendix.
} 
Table 1 refers to the sample of firms that were set up by a founder previously employed by a private company. It shows how the founder rates the importance of the knowledge transfer for the establishment of her firm. For $10 \%$ of the firms, new ideas that emerged from the founder's former employment were essential for the formation of the firm. Additionally $28 \%$ of the firms indicate that new ideas were of great importance for the establishment of the firm, $62 \%$ of the firms assign no or only minor importance to new ideas. Specific skills that the founders have acquired during their work for a private company were more frequently pointed out to be essential (33\%) or of great importance (48\%). Only a minority of the interviewees (19\%) regard skills that they acquired during the employment in a private company as unimportant or at most of minor importance. In order to give a representative picture of the importance of knowledge transfer for the establishment of new firms in Germany, Table 1 also reports population weighted shares. The population weighted shares do not differ significantly from the sample shares. ${ }^{4}$

Table 1: Importance of knowledge transfer for the establishment of a new firm

\begin{tabular}{|c|c|c|c|c|c|c|}
\hline & $\mathrm{N}$ & $\begin{array}{c}\text { ideas } \\
\text { sample } \\
\text { shares }\end{array}$ & $\begin{array}{c}\text { population- } \\
\text { weighted } \\
\text { shares }\end{array}$ & $\mathrm{N}$ & $\begin{array}{c}\text { skills } \\
\text { sample } \\
\text { shares }\end{array}$ & $\begin{array}{c}\text { population- } \\
\text { weighted } \\
\text { shares }\end{array}$ \\
\hline Essential & 342 & 9.8 & 7.6 & 1,143 & 32.7 & 28.6 \\
\hline Great importance & 969 & 27.9 & 26.4 & 1,677 & 48.0 & 45.9 \\
\hline Minor importance & 1,052 & 30.3 & 29.0 & 370 & 10.6 & 14.4 \\
\hline No importance & 1,113 & 32.0 & 37.0 & 301 & 8.6 & 11.2 \\
\hline Total & 3,476 & 100 & 100 & 3,491 & 100 & 100 \\
\hline
\end{tabular}

Note: Only firms with at least one founder who previously worked for a private company.

Source: KfW/ZEW Start-Up Panel, authors’ calculations.

Obviously, founders are likely to benefit from employment in a private firm. They accumulate experience, knowledge and skills. It is hence not surprising that the majority of those founders that previously worked for a private company regard skills they acquired as essential or at least of great importance for the formation of their firm. However, in many theoretical models of the emergence of spinoffs they are based on some sort of innovation and commercialise innovative products or processes the incubator firm is either not willing or not able to commercialise itself (see section 2). In line with these models, we believe that the mere transfer of skills does not adequately characterise a spinoff. We think that the notion of spinoffs as innovation-based start-ups is better captured by the transfer of ideas and define a spinoff as a start-up for whose establishment new ideas that emerged from the founder's work for a private company were essential. In other words: a spinoff is a start-up that could not have been established without the transfer and subsequent commercialisation of an idea the founder developed in

\footnotetext{
${ }^{4}$ In the following we only document unweighted descriptive statistics.
} 
the course of her work for a private company. According to this definition, the share of spinoffs in our sample amounts to $10 \%$, which is equivalent to 342 observations (see Table 1). Please keep in mind that the sample in Table 1 comprises of only those start-ups that have at least one founder who previously worked for a private company.

It is important to note that our definition of spinoffs covers ideas that were essential for the establishment of the spinoff and not on ideas that were essential for the success of the spinoff. The founder of a spinoff wants to pursue and commercialise the new idea she developed. In this sense, the new idea is essential for the founder's decision to start the spinoff. Whether or not the new idea is economically successful has to be proven on the market during the spinoff's post-entry period.

In order to get a deeper insight into the characteristics of the idea that was essential for the establishment of the firm, the questionnaire asked all spinoffs to precisely describe this idea. When classifying these free-text responses, 39\% of all spinoffs are based on the transfer of a technological idea they have incorporated either into a new good, new software or new production process. $38 \%$ are based on the invention of a new service, $9 \%$ were established with the idea to improve the quality of existing services or to enhance processes of service delivery. New management or marketing concepts account for $19 \%$ of the ideas. ${ }^{5}$ Frequently, the new ideas are rather incremental changes of existing goods, services, production processes or management concepts, e.g. a special catering service for allergic persons or a craftsman who invented an improved way of floor tiling. This matches with Klepper and Sleeper (2005) who observe that spinoffs in the laser industry offer variants of lasers produced by their incubator firms.

A further differentiated picture of spinoffs emerges when we examine the relationship between the spinoff's good or service and the incubator firm's good or service. $66 \%$ of all spinoffs in the data set entered the market with a similar but improved product, another $8 \%$ of the firms produce a similar product without any further improvement compared to the incubator firm's product. Thus, about three quarters of spinoffs operate in the same industry as their incubator firm. However, a significant share of spinoffs operates at another stage in the value added chain, and accordingly in a different industry, acting as suppliers or customers (17\% and $6 \%$ of the spinoffs respectively) of the incubator firms.

\section{Descriptive Statistics}

\subsection{Setup of the baseline model}

The subsequent empirical analysis requires choosing the selection of a group of start-ups to which spinoffs will be compared and the choice of the observation year of firm outcome. We setup a baseline model for both the descriptive analyses and the subsequent econometric examinations.

\footnotetext{
${ }^{5}$ Some interviewees indicated more than one idea, therefore the sum of shares exceeds $100 \%$.
} 
In our baseline setting, spinoffs (342 firms) are compared to start-ups that (like spinoffs) have at least one founder who previously worked for a private company, but for which (unlike spinoffs) new ideas from the founder's previous employment were not essential. We refer to this comparison group as 'non-spinoffs'. According to the left column of Table 1, the comparison group of non-spinoffs encompasses 3,134 firms. We require that the founders of the non-spinoffs were previously employed by a private company because we expect start-ups of the same origin to be a more appropriate comparison group. Moreover, the restriction allows us to consider variables that characterise the founder's occupation in the private company when estimating the probability of observing a spinoff. We choose 2009 as the observation year of employment growth and innovation activities because 2009 is the only year for which data on employment and innovations are available for all spinoffs in the data set. In sections 6.2 to 0 , we will depart from this baseline setting and analyse whether or not the results will change for different settings of the model.

\subsection{Descriptive statistics on employment growth}

Table 2 depicts the number of employees as well as measures of employment growth for spinoffs and the comparison group of non-spinoffs. The number of employees is measured in full-time equivalents and includes the number of founders, full-time and part-time employees, mini-jobbers ${ }^{6}$, apprentices and founders' family members that work in the firm without being paid. At time of start-up, the number of employees of spinoffs averaged 2.7 employees. At the end of 2009, corporate spinoffs em-

Table 2: Employment in spinoffs and non-spinoffs

\begin{tabular}{|c|c|c|c|c|c|c|c|}
\hline & \multirow{2}{*}{$\begin{array}{l}\text { \# obser- } \\
\text { vations }\end{array}$} & \multirow{2}{*}{ mean } & \multicolumn{5}{|c|}{ percentiles } \\
\hline & & & $10 \%$ & $25 \%$ & $50 \%$ & $75 \%$ & $90 \%$ \\
\hline \multicolumn{8}{|l|}{ Spinoffs } \\
\hline Employees at start-up & 298 & 2.71 & 1.00 & 1.00 & 2.00 & 3.00 & 5.25 \\
\hline Employees 2009 & 302 & 5.68 & 1.00 & 2.00 & 3.25 & 6.25 & 11.25 \\
\hline $\begin{array}{l}\text { Geometric employment growth } \\
\text { rate (in \%) (start-up - 2009) }{ }^{\mathrm{a}}\end{array}$ & 293 & 19.36 & -5.90 & 0.00 & 10.06 & 31.40 & 60.05 \\
\hline Birch Index (start-up - 2009) ${ }^{a}$ & 288 & 9.97 & -0.50 & 0.00 & 1.50 & 6.00 & 25.78 \\
\hline \multicolumn{8}{|l|}{ Non-spinoffs } \\
\hline Employees at start-up & 2,818 & 2.38 & 1.00 & 1.00 & 1.50 & 3.00 & 4.50 \\
\hline Employees 2009 & 2,849 & 4.11 & 1.00 & 1.00 & 2.25 & 4.50 & 8.50 \\
\hline $\begin{array}{l}\text { Geometric employment growth } \\
\text { rate (in \%) (start-up - 2009) }{ }^{\mathrm{a}}\end{array}$ & 2,772 & 14.76 & -5.43 & 0.00 & 5.74 & 25.74 & 45.77 \\
\hline Birch Index (start-up - 2009) ${ }^{a}$ & 2,769 & 6.04 & -0.44 & 0.00 & 0.31 & 4.00 & 14.76 \\
\hline
\end{tabular}

a Observations below the 1st and above the 99th percentiles excluded.

Source: KfW/ZEW Start-Up Panel, authors’ calculations.

\footnotetext{
${ }^{6}$ According to German law, mini jobbers are marginally employed persons who work either part-time or shorttime with a maximum annual salary of 4.800 Euro.
} 
ployed on average 5.7 employees. The distribution of the number of employees is highly right-skewed. In 2009, for instance, the median number of employees of spinoffs amounts to 3.25 persons, $10 \%$ of spinoffs had 11.25 and more employees.

The number of employees of non-spinoffs is slightly smaller than that of spinoffs both at start-up and in 2009. Non-spinoffs started their business with a mean number of 2.4 employees, which grew to an average of 4.1 employees at the end of 2009. Again, the distribution of the number of employees is right-skewed. In 2009, half of non-spinoffs employed at most 2.25 persons, the $10 \%$ largest nonspinoffs had at least 8.50 employees.

According to a t-test on the equality of means both the average number of employees at start-up and at the end of 2009 differ significantly between spinoffs and non-spinoffs (Table 3). The KolmogorovSmirnov test is used to test three hypotheses: (i) that the distribution of the number of employees is different for spinoffs and non-spinoffs, (ii) that the distribution of the number of employees for spinoffs first order stochastically dominates the distribution for non-spinoffs, (iii) that the distribution of the number of employees for non-spinoffs first order stochastically dominates the distribution for spinoffs. As reported in Table 3, the first two hypotheses cannot be rejected for both the number of employees at start-up and in 2009, while the third hypothesis is clearly rejected. Thus, we can conclude that spinoffs are significantly larger in terms of the number of employees than non-spinoffs.

Table 3: Tests for differences in employment between spinoffs and non-spinoffs

\begin{tabular}{l|cc|ccc}
\hline & \multicolumn{2}{|c|}{$\begin{array}{c}\text { t-test for difference } \\
\text { in means }\end{array}$} & \multicolumn{3}{c}{ Kolmogorov-Smirnov test $^{\mathrm{b} \text {-value })^{\mathrm{c}}}$} \\
& $\begin{array}{c}\mathrm{X}_{\text {spinoff }}- \\
\mathrm{X}_{\text {non-spinoff }}\end{array}$ & $\mathrm{p}$-value & $\begin{array}{c}\text { difference: } \\
\text { yes }\end{array}$ & $\begin{array}{c}\text { spinoffs } \\
\text { f-o dominate } \\
\text { non-spinoffs }\end{array}$ & $\begin{array}{c}\text { non-spinoffs } \\
\text { f-o dominate } \\
\text { spinoffs }\end{array}$ \\
\hline Employees at start-up & 0.325 & 0.040 & 0.000 & 0.000 & 0.954 \\
Employees 2009 & 1.578 & 0.001 & 0.000 & 0.000 & 0.999 \\
$\begin{array}{l}\text { Geometric employment growth } \\
\text { rate (in \%) (start-up - 2009) }\end{array}$ & 4.607 & 0.015 & 0.017 & 0.010 & 0.903 \\
Birch Index (start-up - 2009) $^{\mathrm{a}}$ & 3.933 & 0.013 & 0.013 & 0.008 & 0.920 \\
\hline
\end{tabular}

${ }^{\text {a }}$ Observations below the 1st and above the 99th percentiles excluded.

$\mathrm{b}$ The t-test does not assume equal variances for both groups.

${ }^{\mathrm{c}} \mathrm{A}$ p-value of 0.05 (or smaller) indicates that the hypothesis described in the header on the column cannot be rejected at an level of significance of $5 \%$ (or less).

Source: KfW/ZEW Start-Up Panel, authors’ calculations.

The small size of start-ups impedes finding an appropriate outcome variable to measure employment growth, since a small change in the absolute number of employees is often associated with an extremely high employment growth rate. Therefore, we decided to use three different measures for employment growth for the period from start-up to the end of 2009: the annualised geometric employment growth rate, the Birch Index (Birch, 1987), and the absolute change in employment. As shown in Table 2, spinoffs exhibit on average an annual employment growth rate of $19 \%$, whereas non-spinoffs 
grow on average by $15 \%$ per year. ${ }^{7}$ Both the t-test and the Kolmogorov-Smirnov test indicate that the annual employment growth rate for spinoffs is significantly higher than for non-spinoffs (Table 3).

As a second measure for employment growth we calculate the Birch Index (BI), which is a combination of absolute and relative growth and is defined as

$$
B I_{i}=\left(E_{t i}-E_{0 i}\right) \frac{E_{t i}}{E_{0 i}},
$$

with $E_{t i}$ and $E_{0 i}$ as the number of employees of firm $i$ at the end and at the beginning of the growth period respectively. The Birch Index gives an average value of 9.97 for spinoffs, which exceeds the mean value of the Birch Index for non-spinoffs (6.04; see Table 2). Again, the t-test and the Kolmogorov-Smirnov test prove that differences in both the mean and the entire distribution of the Birch Index between spinoffs and non-spinoffs are statistically significant (Table 3).

Our third measure of employment growth is the number of new employees measured in full-time equivalents that entered the newly founded firm in the period from start-up to the end of 2009. The absolute change in the number of employees is divided into five classes: (i) reduction in employment since start-up, (ii) no change in employment, (iii) employment increase of up to one person, (iv) employment increase of more than one and up to five persons, (v) employment increase of more than five persons. Pearson's $\chi^{2}$ tests on independence reveal that non-spinoffs exhibit a significantly higher share of firms with no change in employment, whereas the share of firms that extended their workforce by more than five employees is significantly higher for spinoffs (Table 4). To sum up the results of the descriptive analysis of employment growth, we find that spinoffs exhibit significantly higher employment growth than non-spinoffs. This result holds for all three measures of employment growth.

Table 4: Differences in the number of new employees from start-up to 2009 between spinoffs and non-spinoffs

\begin{tabular}{l|cccc|cc}
\hline & \multicolumn{2}{|c}{ spinoff } & \multicolumn{2}{c}{ non-spinoff } & \multicolumn{2}{c}{ Pearson } \\
& $\#$ & $\%$ & $\#$ & $\%$ & $\chi^{2}(1)$ & p-value \\
\hline Number of new employees: $<0$ & 42 & 14.09 & 388 & 13.76 & 0.025 & 0.875 \\
Number of new employees: 0 & 69 & 23.15 & 879 & 31.18 & 8.205 & 0.004 \\
Number of new employees: $>0-1$ & 56 & 18.79 & 570 & 20.22 & 0.342 & 0.558 \\
Number of new employees: $>1-5$ & 84 & 28.19 & 738 & 26.18 & 0.560 & 0.454 \\
Number of new employees: $>5$ & 47 & 15.77 & 244 & 8.66 & 16.125 & 0.000 \\
\hline Total & 298 & 100 & 2,819 & 100 & & \\
\hline
\end{tabular}

Source: KfW/ZEW Start-Up Panel, authors’ calculations.

\footnotetext{
${ }^{7}$ Employment growth rate as well as the Birch Index and R\&D intensity (see below) are trimmed by excluding observations below the 1st and above the 99th percentiles. We also experimented with different definitions of outliers but our core results remain unchanged.
} 


\subsection{Descriptive statistics on innovation activities}

Analysing post-entry innovation activities, we distinguish between the input into the innovation process and innovation output. As measure for innovation input we use a firm's engagement in Research and Development (R\&D). Our measures of innovation output are market novelties, product as well as process innovations. Following the Oslo Manual (OECD, 2005), a market novelty is a product the firm is the first to introduce into the market. The market can be the firm's local market, the national (read: German) market or the world market. In the latter case, we refer to this product as a world market novelty. A product innovation is a new or significantly improved good or service that is new to the firm, i.e. it is an innovation for that firm. A process innovation is defined as a new or significantly improved process for the production of goods or services that is new to the firm, although it may have been implemented by another firm before.

As Table 5 shows, $43 \%$ of spinoffs in our data set conducted in-house R\&D in 2009. The respective share for non-spinoffs amounted to $21 \%{ }^{8}$ Pearson's $\chi^{2}$ test proves that this difference is statistically significant. A firm's R\&D intensity is defined as the ratio of R\&D expenditure to total sales. In 2009, the mean R\&D intensity of spinoffs was 7\%. Non-spinoffs spent on average $3 \%$ of their total sales on $\mathrm{R} \& \mathrm{D}$. The t-test and the Kolmogorov-Smirnov test prove that differences in both the mean and the entire distribution of the R\&D intensity between the two groups are statistically significant.

Table 5: Differences in innovation indicators in 2009 between spinoffs and non-spinoffs

\begin{tabular}{l|cc|cc}
\hline & spinoff & non-spinoff & $\begin{array}{c}\text { Pearson } \\
\chi^{2}(1)\end{array}$ & p-value \\
\hline In-house R\&D activities (0/1) & 42.72 & 20.50 & 76.982 & 0.000 \\
\hline World market novelty & 10.33 & 4.27 & 21.597 & 0.000 \\
Market novelty & 25.67 & 13.17 & 34.462 & 0.000 \\
Product innovation & 49.17 & 32.97 & 31.599 & 0.000 \\
Process innovation & 31.89 & 18.74 & 29.429 & 0.000 \\
\hline
\end{tabular}

Source: KfW/ZEW Start-Up Panel, authors’ calculations.

Innovation output is also significantly higher for spinoffs than for non-spinoffs. $10 \%$ of spinoffs introduced a world market novelty in 2009 whereas only $4 \%$ of non-spinoffs did so. Almost half of spinoffs launched a product innovation in 2009 while it was only one third of non-spinoffs. Similar differences are found for process innovations.

In our analysis of innovation activities we primarily focus on firms' innovation behaviour in one observation year. However, for characterising firms as 'think tanks' a longer-term perspective on post-

\footnotetext{
${ }^{8}$ Please recall that the statistics displayed in Table 5 are unweighted sample shares. Since half of the firms surveyed by the KfW/ZEW Start-Up Panel operate in a high-technology industry, the sample shares indicating innovation activities are upward biased. Using population weights reduces the share of spinoffs (non-spinoffs) that carried out in-house R\&D in 2009 to 27\% (14\%).
} 
entry innovation activities is useful. Restricting ourselves to those firms that participated in each of the three surveys of the KfW/ZEW Start-Up Panel available for our study, it turns out that $16 \%$ of spinoffs introduced a product innovation in each observation year from 2007 to 2009. By contrast, only $10 \%$ of non-spinoffs showed this pattern of innovation activities. Similarly, $10 \%$ of spinoffs and $4 \%$ of nonspinoffs implemented a process innovation in each year from 2007 to 2009. These differences are statistically significant according to Pearson's $\chi^{2}$ test. ${ }^{9}$ Thus, according to descriptive statistics, spinoffs are more innovative not only at one point in time but also over a longer time period after firm formation.

\section{Estimation Method}

In order to determine the causal effect of being a spinoff on employment growth and post-entry innovation activities we apply nearest neighbour propensity score matching. The basic idea of propensity score matching is to estimate the causal effect of a treatment, in our case being a spinoff, by comparing the mean of outcomes of treated entities (spinoffs) with the mean of outcomes of a control group of non-treated entities (non-spinoffs). The matching approach aims that spinoffs in the treatment group and non-spinoffs in the control group share similar, ideally identical, observable pre-treatment characteristics. Remaining differences in the mean outcome of both groups cannot then be attributed to varying observable pre-treatment characteristics but to the fact of being a spinoff.

The average causal effect of being a spinoff, the average treatment effect of the treated, is given by

$$
A T T:=E\left[Y^{1}-Y^{0} \mid \text { spinoff }=1\right]=E\left[Y^{1} \mid \text { spinoff }=1\right]-E\left[Y^{0} \mid \text { spinoff }=1\right],
$$

where $E\left[Y^{1} \mid\right.$ spinoff $\left.=1\right]$ is the expected outcome of spinoffs and $E\left[Y^{0} \mid\right.$ spinoff $\left.=1\right]$ is the expected outcome of the same firms if they were non-spinoffs. Since a spinoff cannot be observed in the regime of non-spinoffs, $E\left[Y^{0} \mid\right.$ spinoff $\left.=1\right]$ cannot be calculated using non-experimental survey data. However, as shown by Rubin (1977) and Rosenbaum and Rubin (1983) the average counterfactual outcome of a sample's treated entities (spinoffs) can be estimated in an unbiased way by the outcome of non-treated entities (non-spinoffs) - provided that both groups have similar, ideally identical, realisations of a vector $X$ of pre-treatment characteristics. ${ }^{10}$ Equation (2) can then be written as

$$
A T T:=E\left[Y^{1} \mid \text { spinoff }=1, X=x\right]-E\left[Y^{0} \mid \text { spinoff }=0, X=x\right] .
$$

\footnotetext{
${ }^{9}$ The number of observations of firms with (world) market novelties is too small to report complete sequences of these innovation indicators.

${ }^{10}$ The underlying assumption is that treatment and outcome are independent for entities with the same realisations $x$ of the vector $X$ (Conditional Independence Assumption, CIA, also referred to as the unconfoundedness or selection on observables assumption). For the CIA to be valid, the vector $X$ must include all covariates that simultaneously influence both treatment and outcome (cf. Rubin, 1977).
} 
The vector $X$ of pre-treatment characteristics may have a very high dimension. Rosenbaum and Rubin (1983) showed that it is possible to reduce the problem of multidimensionality by choosing a function of $X$, called a balancing score, as the conditioning variable. A valid balancing score is the conditional probability (propensity score) of being a spinoff that results from a probit estimation and is given by $\Phi\left(x_{i}^{\prime} \hat{\beta}\right)$, the cumulated density function of the standard normal distribution.

As Lechner (1999) argues, matching on the bounded propensity score leads to undesirable asymmetry if the predicted probability of receiving treatment is close to 0 or 1 . Our data set contains a large number of non-spinoffs whose bounded propensity score is close to 0. We therefore follow Lechner (1999) and use the unbounded propensity score $x_{i}^{\prime} \hat{\beta}$ instead of the bounded propensity score $\Phi\left(x_{i}^{\prime} \hat{\beta}\right)$ as the main matching variable. Standard errors of the ATT are calculated according to Abadie and Imbens (2006: p. 250). ${ }^{11}$

The (unbounded) propensity score indicating the probability of whether or not a firm observed in the data set is a spinoff, is estimated using a vector of exogenous covariates $X$. This vector includes founder-specific variables measured at the time of start-up and variables that are related to the founder's employment in the incubator firm, measured at the time when the founder left the incubator firm. The variables used as covariates are presented below.

The age of the founder proxies the founder's general professional experience in the year of start-up and is measured in logarithmic years. Since previous studies found out that the relationship between a person's age and her creativity and innovative performance - as a prerequisite to develop a new idea is inversely U-shaped (see, e.g., Frosch, 2009), we also included the squared value of age. In case of a team foundation, information on each member of the team of founders is available in the data set. In the econometric model, this information is aggregated by considering the age of the oldest founder.

Besides general experience, we consider specific industry experience of the founder in the year of start-up, measured as the (logarithmic) number of years of working experience in the same sector of the start-up. In case of a team foundation, we observe the years of experience of the founder who worked the longest time period in the relevant industry. To account for a potential non-linear effect, we include the variable's squared value into the regression model.

The founders' education enters the empirical model in two dimensions: the founder's highest educational degree and her field of specialisation. The educational degree is differentiated into eight categories: doctoral degree (including a German Habilitation), university degree without a doctoral degree, degree from a university of applied sciences (Fachhochschule), university of corporate education

\footnotetext{
${ }^{11}$ The asymmetry of the bounded propensity score is relevant for matching techniques others than one-to-one nearest neighbour matching. In order to test for the robustness of the chosen matching methodology, we experimented with other matching techniques like nearest neighbour propensity score matching with calliper or kernel matching with varying bandwidths of the kernel function. The main conclusions, however, do not change.
} 
(Berufsakademie/duale Hochschule), commercial college (Berufsfachschule or Handelsschule), master craftsman (Meister), vocational training, and no vocational qualification. ${ }^{12}$ Each educational degree is classified into four fields of specialisation: a degree in natural sciences (including medicine), engineering and technology, social sciences (including studies in law), and humanities. Please note that the indicators of the different fields of specialisation encompass both founders with a university degree and those with a vocational training. Thus, the studied chemist and the chemical laboratory worker are both classified into the field of natural sciences, the economist, the lawyer or the office clerk fall into the field of social sciences. ${ }^{13} 14$

The foundation of the spinoff might have been supported or even initiated by the incubator firm. In order to support the spinoff, the incubator firm may allow its previous employee to patent an idea that she developed during her work for the incubator firm. This effect is accounted for by a dummy variable indicating firms with at least one founder whom a patent was granted prior to the start-up of the firm.

The vector of founder-specific variables is completed by two dummy variables indicating whether a start-up had at least one female founder or at least one founder with a migration background. We further include a dummy variable indicating firms that were established by a team of founders.

Two sets of explanatory variables characterise the founder's previous employment in a private company. First, we classify the founders according to the position they occupied in their former firm. We distinguish between former executive directors, executive employees and other employees. The first two variables approximate experience in managing a company or corporate operations. Our second set of variables describes the former firm's business unit the founder worked in: production, management, sales or research.

The size of the incubator firm may have an effect on the probability of being a spinoff because, for instance, of different learning possibilities. The firm size of the former employer is measured by the (logarithmic) number of employees and its squared value. In case of a spinoff we include the size of the firm where the essential idea accrued, in case of a non-spinoff we consider the size of the founder's last former employer. In case of a non-spinoff founded in a team we measure the size of the largest former employer of any of the founders.

\footnotetext{
${ }^{12}$ For details on the German education system, see European Commission (2010) or, for a short overview, European Commission (2011).

${ }^{13}$ There are a small number of founders that could not be coded into the four predetermined fields of specialisation. This includes, e.g., founders with a degree in sport science or founders without a completed vocational training.

${ }^{14}$ If a firm was set up by a team of founders that hold different highest degrees this firm is represented by a set of dummy variables indicating these different degrees. As a consequence, the eight variables measuring educational degree are not orthogonal to each other. Thus, we do not have a base category for educational degree in the regression equation. The same argument applies for the set of variables representing the four different fields of specialisation.
} 
Finally, our regressions include sets of dummy variables for the stratification criteria industry sector, year of start-up (2005 to 2009), and promotion by KfW. Table 14 in the appendix reports mean values for all explanatory variables based on those observations that enter the baseline regression. Due to missing values in the covariates, the final sample that is used for the matching analysis comprises 3,151 firms, 302 spinoffs and a comparison group of 2,849 non-spinoffs. From the latter the matched controls will be selected.

\section{Estimation Results}

\subsection{Baseline model}

Table 6 shows the results of the probit regression for our baseline model, estimating the probability that a firm observed in the sample is a spinoff. Spinoffs tend to be firms with higher human capital endowment of founders than non-spinoffs. The probability that a firm is a spinoff is higher for startups whose founders have a university degree than for start-ups whose founders have an educational degree below university level. The same holds for start-ups whose founders could gain leadership experience at their former employer. A reasonable explanation for this result is that both university graduates and former directors or managers are better able to recognise business opportunities at the incubator firm. A high level of formal education might put employees in a good position to combine and recombine information and knowledge in order to work out a business idea. The probability to observe a spinoff is also higher when the start-up is founded by a team. This might reflect the fact that team members were colleagues at the incubator firm. ${ }^{15}$ The probability to observe a spinoff is also related to founders' industry experience. It increases with the industry experience of the founders up to about 11 years and decreases afterwards.

The probability to observe a spinoff increases if the founders worked in the R\&D department at their former employer. It can be expected that a series of ideas emerges in R\&D departments which can be further developed into business ideas. In addition, a start-up is more likely to be a spinoff if the founders held patents before founding.

The probability to observe a spinoff shows a U-shaped relationship with the size of the previous employer. It decreases up to a size of about 400 employees and increases afterwards. Small firms seem to lack the capabilities to implement the ideas employees come up with. On the contrary, employees' ideas are more likely to be exploited within medium-sized incubator firms. In large firms, bureaucracy and established organisation structures may be impeding factors for pursuing new ideas (Hyytinen and Maliranta, 2008).

\footnotetext{
${ }^{15}$ Unfortunately, this information is not available in our data to check this conjecture.
} 
Table 6: Probit estimation of the probability of being a spinoff (baseline model)

\begin{tabular}{|c|c|c|c|}
\hline & marginal effect & $\begin{array}{c}\text { robust standard } \\
\text { error }\end{array}$ & \\
\hline Age of the (oldest) founder at start-up (ln) & 0.220 & 0.533 & \\
\hline Age of the (oldest) founder at start-up (ln) ${ }^{2}$ & -0.035 & 0.073 & \\
\hline Founder's industry experience at start-up (ln) & 0.063 & 0.022 & $* * *$ \\
\hline Founder's industry experience at start-up $(\ln )^{2}$ & -0.013 & 0.006 & $* *$ \\
\hline \multicolumn{4}{|l|}{ Educational degree } \\
\hline $\mathrm{PhD}$ & 0.098 & 0.043 & $* * *$ \\
\hline university & 0.035 & 0.021 & $*$ \\
\hline university of applied sciences & 0.020 & 0.020 & \\
\hline university of corporate education & -0.001 & 0.033 & \\
\hline commercial college & 0.030 & 0.030 & \\
\hline master craftsman & -0.012 & 0.017 & \\
\hline vocational training & 0.009 & 0.018 & \\
\hline no vocational training & 0.022 & 0.052 & \\
\hline \multicolumn{4}{|l|}{ Field of specialisation } \\
\hline natural sciences & -0.033 & 0.014 & $* *$ \\
\hline engineering and technology & -0.018 & 0.016 & \\
\hline social sciences & -0.008 & 0.015 & \\
\hline humanities & 0.001 & 0.025 & \\
\hline Own patents before start-up & 0.119 & 0.050 & $* * *$ \\
\hline Female founder & -0.003 & 0.013 & \\
\hline Founder with migration background & 0.001 & 0.020 & \\
\hline Team foundation & 0.051 & 0.017 & $* * *$ \\
\hline \multicolumn{4}{|l|}{ Founder's position at previous employer } \\
\hline executive director & 0.044 & 0.026 & $*$ \\
\hline executive employee & 0.044 & 0.020 & $* *$ \\
\hline other employee & 0.014 & 0.023 & \\
\hline \multicolumn{4}{|l|}{ Founder's business unit at previous employer } \\
\hline production/provision of services & 0.002 & 0.013 & \\
\hline sales & 0.009 & 0.012 & \\
\hline administration & 0.015 & 0.014 & \\
\hline research & 0.044 & 0.020 & $* *$ \\
\hline Size of previous employer (ln(number of employees)) & -0.024 & 0.006 & $* * *$ \\
\hline Size of previous employer $(\ln (\text { number of employees }))^{2}$ & 0.002 & 0.001 & $* * *$ \\
\hline \multicolumn{4}{|l|}{ Industry (ref. wholesale and retail trade) } \\
\hline cutting-edge technology manufacturing & 0.078 & 0.037 & $* *$ \\
\hline high-tech manufacturing & -0.013 & 0.025 & \\
\hline technology-intensive services & -0.001 & 0.019 & \\
\hline software supply and consultancy & 0.052 & 0.032 & $*$ \\
\hline non-high-tech manufacturing & 0.005 & 0.022 & \\
\hline skill-intensive services & 0.015 & 0.026 & \\
\hline other business-oriented services & 0.008 & 0.031 & \\
\hline consumer-oriented services & 0.041 & 0.026 & $*$ \\
\hline construction & 0.008 & 0.023 & \\
\hline \multicolumn{4}{|l|}{ Year of firm formation (ref. 2005) } \\
\hline 2006 & 0.010 & 0.014 & \\
\hline 2007 & 0.014 & 0.014 & \\
\hline 2008 & 0.001 & 0.015 & \\
\hline Number of observations & & 3,151 & \\
\hline Log pseudolikelihood & & -925.496 & \\
\hline McFadden's $\mathrm{R}^{2}$ & & 0.070 & \\
\hline
\end{tabular}

$* * *, * *, *$ depict significance at the $1 \%, 5 \%$ and $10 \%$ level respectively and correspond to the test of the underlying coefficient being zero. Additional control variable indicating firms promoted by KfW included.

Source: KfW/ZEW Start-Up Panel, authors’ calculation. 
Concerning industries, the probability to observe a spinoff increases when a firm is founded in cutting edge technology manufacturing. Compared to the reference industry wholesale and retail trade the probability to observe a spinoff is also positively affected if a firm is founded in the software sector or in consumer-oriented services.

When applying nearest neighbour propensity score matching ${ }^{16}$, the quality of the match appears to be good. ${ }^{17}$ After matching, no significant differences in the observable pre-treatment characteristics between the groups were detectable, confirming the balancing property of the match. Table 15 in the appendix displays descriptive statistics of all pre-treatment variables after matching. The p-value of an LR-test for joint insignificance of all the regressors in a probit on the matched samples is at least $0.92 .^{18}$

Table 7 shows the average treatment effect with respect to our outcome measures for the baseline model. Spinoffs do not benefit from an essential idea in terms of employment growth but in terms of

Table 7: Causal effect of being a spinoff on employment growth and innovations activities: baseline model

\begin{tabular}{|c|c|c|c|c|c|c|}
\hline & $\begin{array}{c}\text { number of } \\
\text { matched } \\
\text { pairs }\end{array}$ & spinoffs & $\begin{array}{c}\text { associated } \\
\text { controls }\end{array}$ & $\begin{array}{c}\text { difference } \\
\text { in out- } \\
\text { come } \\
\end{array}$ & $\begin{array}{l}\text { standard } \\
\text { error of } \\
\text { difference }\end{array}$ & \\
\hline \multicolumn{7}{|l|}{ Employment growth (start-up - 2009) } \\
\hline Employment growth rate & 287 & 0.194 & 0.166 & 0.029 & 0.026 & \\
\hline Birch Index & 282 & 9.935 & 9.152 & 0.783 & 2.137 & \\
\hline Number of new employees: $<0$ & 292 & 0.140 & 0.147 & -0.007 & 0.028 & \\
\hline Number of new employees: 0 & 292 & 0.233 & 0.260 & -0.027 & 0.037 & \\
\hline Number of new employees: $>0-1$ & 292 & 0.192 & 0.192 & 0.000 & 0.035 & \\
\hline Number of new employees: > $1-5$ & 292 & 0.281 & 0.264 & 0.017 & 0.039 & \\
\hline Number of new employees: $>5$ & 292 & 0.154 & 0.137 & 0.017 & 0.030 & \\
\hline \multicolumn{7}{|l|}{ Innovation 2009} \\
\hline In-house $\mathrm{R} \& \mathrm{D}$ activities (0/1) & 296 & 0.416 & 0.260 & 0.155 & 0.039 & **** \\
\hline R\&D intensity & 222 & 0.066 & 0.034 & 0.032 & 0.012 & **** \\
\hline World market novelty & 294 & 0.088 & 0.068 & 0.020 & 0.021 & \\
\hline Market novelty & 294 & 0.245 & 0.177 & 0.068 & 0.034 & ** \\
\hline Product innovation & 295 & 0.485 & 0.366 & 0.119 & 0.041 & $* * *$ \\
\hline Process innovation & 295 & 0.312 & 0.220 & 0.092 & 0.039 & $* *$ \\
\hline
\end{tabular}

Note: $* * *, * *, *$ depict significance of the difference in outcome at the $1 \%, 5 \%$ and $10 \%$ level respectively; standard errors of the ATT are calculated according to Abadie and Imbens (2006).

Source: KfW/ZEW Start-Up Panel, authors’ calculation.

\footnotetext{
${ }^{16}$ Propensity score matching was conducted using the Stata programme psmatch2 (Leuven and Sianesi, 2003).

${ }^{17}$ The common support condition that requires that conditional on the vector $X$ firms have a positive probability of being both spinoffs and non-spinoffs is fulfilled for all but six spinoffs.

${ }^{18}$ The p-value varies slightly depending on the outcome measure because not all outcome measures can be calculated for all firms due to missing values.
} 
innovation. After matching, there are no significant differences in any measure of employment growth between spinoffs and non-spinoffs. However, spinoffs exhibit significantly higher innovation activities than non-spinoffs. This holds for all innovation measures except for the introduction of a world market novelty.

An essential idea transferred from an incumbent firm can be interpreted either as an input factor into or a stimulus for the innovation process of the spinoff. In this way, the essential idea enables or at least initiates post-entry innovation activities within a spinoff. For example, if the idea constitutes a new technology developed by the spinoff's founder this technology might be incorporated into various product innovations or it may offer the possibility and stimulate the spinoff to conduct in-house R\&D in order to further develop this technology. The essential idea can also be interpreted as the founder's past innovation experience she gained during her work for the incubator company. As Peters (2009) pointed out in her study of established firms, past innovation experience plays a major role in explaining a firm's generation of innovations over time, leading to persistence in a firm's innovation activities.

However, the treatment effect is not necessarily homogeneous. Some firms may benefit more from the transfer of an essential idea than others. Therefore, for all variables for which we found a significant effect on firm outcome we tested for homogeneity of the treatment effect. In doing so, we applied the Fully Integrated Linear Model (FILM) described by Goodman and Sianesi (2005). FILM is an OLS regression with firm outcome as dependent variable and the treatment variable, all covariates, and a full set of interactions between the treatment and all covariates as explanatory variables. The model is estimated using the full sample of spinoffs and non-spinoffs excluding those firms that do not fulfil the common support condition. ${ }^{19}$ The null hypothesis of no heterogeneity is tested using an F-test for joint significance of all interactions between the treatment variable and the covariates. The results of the Ftests are shown in Table 8. Regarding the introduction of a market novelty and the implementation of process innovations the treatment effect turns out to be homogenous: all firms benefit in the same way from being a spinoff. On the contrary, the treatment effect on R\&D activities and the introduction of product innovations is heterogeneous.

FILM estimations also point out the sources of heterogeneity. The estimated coefficients of the interaction terms indicate that spinoffs that were set up by a founder with a degree in engineering or technology gain more from the transfer of an essential idea than other spinoffs (see Table 16 in the appendix), although the probability to be a spinoff is not influenced by a founder's degree in engineering or technology. The increase in R\&D intensity is higher for spinoffs by founders who have a field of specialisation in social sciences and, interestingly, for spinoffs by founders without a vocational training.

\footnotetext{
${ }^{19}$ The idea behind FILM is to make the OLS regression more flexible and to adjust it to propensity score matching. However, FILM still assumes linearity whereas propensity score matching does not. The common support condition guarantees that FILM, in accordance to the matching approach, only analyses firms that are comparable (cf. Goodman and Sianesi, 2005).
} 
Table 8: Test for homogeneity of the average treatment effect of the treated

\begin{tabular}{|c|c|c|c|}
\hline & F statistic & p-value & \\
\hline In-house $R \& D$ activities $(0 / 1)$ & 1.36 & 0.059 & $*$ \\
\hline R\&D intensity & 1.63 & 0.007 & $* * *$ \\
\hline Market novelty & 1.15 & 0.238 & \\
\hline Product innovation & 1.47 & 0.026 & $* *$ \\
\hline Process innovation & 0.91 & 0.642 & \\
\hline
\end{tabular}

Note: Baseline model. F-test of no heterogeneous effects based on a fully integrated linear model; common support condition applies; ***, **, * depict significance of the test statistic at the $1 \%, 5 \%$ and $10 \%$ level respectively.

Source: KfW/ZEW Start-Up Panel, authors’ calculation.

The treatment effect on R\&D intensity further rises with spinoff founders' industry experience. The impact on the probability of a product innovation increases if the founder of the spinoff holds a degree from a university of corporate education and has previously worked as a researcher, but it decreases if the founder worked in a sales department. ${ }^{20}$

The interpretation of our results as an effect of being a spinoff is based on the assumption of selection on observables (Rubin, 1977). Unobserved factors that influence the probability of being a spinoff can lead to a selection bias and drive the estimated ATT to zero. As a robustness check, we conduct Mantel-Haenszel tests of the Rosenbaum bounds (Rosenbaum, 2002) as described in Aakvik (2001) and Becker and Caliendo (2007). The tests indicate how strongly an unobserved variable must affect the selection into the treatment so that the estimated ATT vanishes. The methodology and the test results are discussed in detail in the technical Appendix to this paper. In short, the results show that being a spinoff is positively related to post-entry R\&D activities even in presence of a 'strong' unobserved factor. The effect on the probability to introduce a product or a process innovation remains positive for a 'moderate' selection bias. However, we have to be cautious when interpreting the ATT on the probability to introduce a market novelty, since this treatment effect is not robust if an unobserved factor exists.

Usually, innovation activities take some time. Thus, one might suspect that it is just the essential idea which is the basis of a spinoff's business model that constitutes the innovation output observed in Table 7. However, we argue that this is not the case. First, the essential idea is not necessarily the same as a new product or a new service. Instead, for a significant number of spinoffs the essential idea is a new marketing or management concept (see section 3.2). Second, the innovation measures refer to the year 2009, which is for most firms several years after foundation. Surely, there are a few start-ups which need up to several years of development time before the introduction of their product, in particular in selected high-tech manufacturing industries. However, only $15 \%$ of the spinoffs in our data set belong

\footnotetext{
${ }^{20}$ Of course, FILM regressions can only provide a first insight into the sources of heterogeneity. A more indepth analysis is required but is beyond the scope of this paper.
} 
either to cutting-edge or to high-technology manufacturing industries. Most relevant in terms of numbers are firms in the service sectors. It is not very likely that these firms introduce their business idea as late as three to five years after foundation. An indication that our conjecture is correct is that $88 \%$ of spinoffs had sales already in the calendar year of start-up, 62\% of spinoff firms were able to break even in the first year. In order to make a sort of a test whether firms generated new knowledge in addition to the essential idea used for firm foundation, we performed nearest neighbour matching for an outcome variable indicating firms that exhibited products new to the firm in at least two years between start-up and 2009. For these firms we can be sure that they introduced at least one product innovation in addition to the idea which was essential for their foundation. The results show that being a spinoff significantly increases the probability to introduce product innovations in at least two years until 2009 (estimated difference of matched pairs: 0.068, standard error: 0.037). ${ }^{21}$

\subsection{Spinoffs: age-specific effects}

The causal effect of an essential idea might depend on the age of the young firms. A reasonable pattern is that an effect on employment only appears when firms are older because the idea has to be established in the market first. If we do not distinguish the firms by age it might be the case that the effect is concealed because we mix up times in the life of a young firm when there cannot be an effect (because the firm is too young) and times when there actually is an effect. In order to check whether there are age-specific effects we estimated the causal effects for each business year a firm is observed in the data. For example, for a firm in its second business year we calculate employment growth measures for the period from start-up until the end of the second business year. With respect to innovation we determine whether the firm had innovation input or innovation output in its second business year.

Table 9 shows the average treatment effect by business year. In order to save space only differences in outcome variables are depicted. With respect to employment growth, significant effects appear only sporadically for particular growth measures and business years. In addition, these effects are only significant at the $10 \%$ level. By contrast, we find significant effects for many innovation measures and ages. Obviously, spinoffs are more active in R\&D than non-spinoffs over the whole time span that we observe them. Up to the fourth business year, they are also more successful in producing market novelties, product and process innovations.

\footnotetext{
${ }^{21}$ In the baseline model, the control group was constructed from the group of start-ups with at least one former employee of an established firm among the founders. It can be argued that all start-ups provide a better basis for the construction of the control group because they include, for example, academic spinoffs might be particularly suitable matching partners for corporate spinoffs. In order to check whether our results are influenced by the choice of the comparison group from which the control group is selected we replicated the analyses with the whole sample of firms. The results were essentially the same as the ones shown in Table 7.
} 
Table 9: Causal effect of being a spinoff on employment growth and innovations activities: agespecific estimations

\begin{tabular}{|c|c|c|c|c|c|c|c|c|}
\hline \multirow{2}{*}{$\begin{array}{l}\text { Differences in outcome in the ... } \\
\text { Employment growth }\end{array}$} & \multicolumn{2}{|c|}{$\begin{array}{c}\ldots 2^{\text {nd }} \text { business } \\
\text { year }\end{array}$} & \multicolumn{2}{|c|}{$\begin{array}{c}\ldots 3^{\text {rd }} \text { business } \\
\text { year }\end{array}$} & \multicolumn{2}{|c|}{$\begin{array}{c}\ldots 4^{\text {th }} \text { business } \\
\text { year }\end{array}$} & \multicolumn{2}{|c|}{$\begin{array}{c}\ldots 5^{\text {th }} \text { business } \\
\text { year }\end{array}$} \\
\hline & & & & & & & & \\
\hline Employment growth rate & \multicolumn{2}{|l|}{0.004} & \multicolumn{2}{|l|}{-0.008} & \multicolumn{2}{|l|}{0.016} & \multicolumn{2}{|l|}{0.029} \\
\hline Birch Index & \multicolumn{2}{|l|}{-1.397} & \multicolumn{2}{|l|}{0.941} & \multicolumn{2}{|l|}{2.073} & 8.661 & $*$ \\
\hline Number of new employees: $<0$ & \multicolumn{2}{|l|}{-0.004} & \multicolumn{2}{|l|}{0.040} & \multicolumn{2}{|l|}{-0.016} & \multicolumn{2}{|l|}{0.017} \\
\hline Number of new employees: 0 & \multicolumn{2}{|l|}{-0.034} & \multicolumn{2}{|l|}{-0.085} & \multicolumn{2}{|l|}{-0.031} & \multicolumn{2}{|l|}{-0.117} \\
\hline Number of new employees: $>0-1$ & \multicolumn{2}{|l|}{0.023} & \multicolumn{2}{|l|}{0.027} & \multicolumn{2}{|l|}{-0.031} & \multicolumn{2}{|l|}{0.000} \\
\hline Number of new employees: > $1-5$ & \multicolumn{2}{|l|}{0.030} & \multicolumn{2}{|l|}{0.000} & \multicolumn{2}{|c|}{$0.093 *$} & \multicolumn{2}{|l|}{0.017} \\
\hline Number of new employees: > 5 & \multicolumn{2}{|l|}{-0.015} & \multicolumn{2}{|l|}{0.018} & \multicolumn{2}{|l|}{-0.016} & \multicolumn{2}{|l|}{0.083} \\
\hline \multicolumn{9}{|l|}{ Innovation activities } \\
\hline In-house R\&D activities (0/1) & 0.189 & $* * *$ & 0.149 & $* * *$ & 0.137 & $* *$ & 0.197 & $* *$ \\
\hline R\&D intensity & 0.037 & $*$ & 0.045 & $* *$ & 0.030 & & 0.065 & $* *$ \\
\hline World market novelty & 0.022 & & 0.000 & & 0.023 & & -0.085 & \\
\hline Market novelty & 0.087 & $* *$ & 0.071 & $*$ & 0.107 & $* *$ & -0.034 & \\
\hline Product innovation & 0.089 & $*$ & 0.070 & & 0.122 & $* *$ & 0.000 & \\
\hline Process innovation & 0.047 & & 0.106 & $* *$ & 0.176 & $* * *$ & 0.083 & \\
\hline
\end{tabular}

Note: ***, **, * depict significance of the difference in outcome at the $1 \%, 5 \%$ and $10 \%$ level respectively, standard errors of the ATT are calculated according to Abadie and Imbens (2006).

Source: KfW/ZEW Start-Up Panel, authors' calculation.

\subsection{Start-ups for which the idea was of at least great importance}

Up to now, we based our definition of the treatment group on whether or not an idea has been essential for the establishment of a firm. However, this might be too narrow because founders are reluctant to call an idea essential or because there are not large differences between an essential idea and an idea of great importance. In this section, we analyse to what extent the results change if we also consider startups whose founders ranked the idea they encountered during their work as employees for an incumbent firm to be of great importance as our treatment group. According to the left column of Table 1, the treatment group now involves 1,311 firms; the comparison group from which the matched controls are selected contains 2,165 firms (start-ups for which an idea was of minor or no importance). Apart from that, the conditions of our baseline model apply.

As depicted in Table 10, we again find an effect on both innovation input and innovation output. In addition to our previous findings we also find an effect on the introduction of a world market novelty. Contrary to our previous results, a firm that is based on an idea of at least great importance has a higher growth rate and a higher Birch Index. Moreover, this firm is less likely to not grow and more likely to recruit more than five employees. A possible reason for the difference of these results in comparison to the results found in the previous sections is that ideas that were essential for the formation of a new firm distinguish from ideas that were 'only' of great importance. Indeed, the descriptions of the trans- 
Table 10: Causal effect of an idea of at least great importance on employment growth and innovation activities

\begin{tabular}{|c|c|c|c|c|c|c|}
\hline & $\begin{array}{c}\text { number of } \\
\text { matched } \\
\text { pairs } \\
\end{array}$ & $\begin{array}{l}\text { idea of at } \\
\text { least great } \\
\text { importance }\end{array}$ & $\begin{array}{l}\text { associated } \\
\text { controls }\end{array}$ & $\begin{array}{l}\text { difference } \\
\text { in out- } \\
\text { come } \\
\end{array}$ & $\begin{array}{c}\text { standard } \\
\text { error of } \\
\text { difference } \\
\end{array}$ & \\
\hline \multicolumn{7}{|c|}{ Employment growth (start-up - 2009) } \\
\hline Employment growth rate & 1,135 & 0.180 & 0.145 & 0.035 & 0.016 & $* *$ \\
\hline Birch Index & 1,140 & 8.445 & 5.914 & 2.531 & 1.106 & $* *$ \\
\hline Number of new employees: $<0$ & 1,165 & 0.136 & 0.156 & -0.021 & 0.020 & \\
\hline Number of new employees: 0 & 1,165 & 0.253 & 0.303 & -0.050 & 0.024 & $* *$ \\
\hline Number of new employees: $>0-1$ & 1,165 & 0.194 & 0.191 & 0.003 & 0.022 & \\
\hline Number of new employees: $>1-5$ & 1,165 & 0.294 & 0.269 & 0.026 & 0.024 & \\
\hline Number of new employees: > 5 & 1,165 & 0.123 & 0.081 & 0.042 & 0.016 & $* * *$ \\
\hline \multicolumn{7}{|l|}{ Innovation activities 2009} \\
\hline In-house $R \& D$ activities (0/1) & 1,176 & 0.330 & 0.230 & 0.099 & 0.024 & $* * *$ \\
\hline R\&D intensity & 910 & 0.054 & 0.034 & 0.020 & 0.008 & $* *$ \\
\hline World market novelty & 1,166 & 0.077 & 0.048 & 0.029 & 0.013 & $* *$ \\
\hline Market novelty & 1,166 & 0.206 & 0.133 & 0.073 & 0.020 & $* * *$ \\
\hline Product innovation & 1,171 & 0.436 & 0.331 & 0.105 & 0.026 & $* * *$ \\
\hline Process innovation & 1,174 & 0.265 & 0.191 & 0.074 & 0.022 & $* * *$ \\
\hline
\end{tabular}

Note: $* * *, * *, *$ depict significance of the difference in outcome at the $1 \%, 5 \%$ and $10 \%$ level respectively; standard errors of the ATT are calculated according to Abadie and Imbens (2006).

Source: KfW/ZEW Start-Up Panel, authors’ calculation.

ferred ideas in the open free-text fields reveal that ideas classified as essential more frequently concern highly specialised, customised products. Although this is no statistical proof, it supports the conjecture that essential ideas tend to target small niche markets that offer less possibilities to grow. In contrast, ideas of great importance tend to be designed to meet the requirements of the mass market. For the latter firms the transferred idea offers growth potential.

\subsection{Start-ups for which specific skills were essential}

As discussed in section 2, knowledge and technology transfer from one firm to another is not restricted to essential or important ideas. With the set of questions designed to classify spinoffs we are able to check the causal effect of specific skills that the founders acquired during their work for an incumbent firm. Among the start-ups of which at least one founder once worked for a private company we identify those start-ups whose founders indicate that the skills acquired at their former employer were essential for setting up the new firm. In order not to confound the impact of essential skills with that of essential ideas we excluded spinoffs from the sample. Thus, this section's analysis is based on 3,149 observations, 931 firms where specific skills were essential and a comparison group of 2,218 firms where specific skills were not essential (right column of Table 1 disregarding spinoffs). 
The probit estimation used to calculate the balancing score (Table 17 in the appendix) reveals that the probability to be a start-up for which specific skills were essential is - in contrast to the probability of being a spinoff - not positively influenced by a $\mathrm{PhD}$ or a university degree of the founder, by patents held before founding or by the founder's previous work in an R\&D department. Instead, the probability that a start-up is based on essential skills increases if the founders are master craftsmen, hold a degree from a commercial college or previously worked in production or sales departments. Similar to the baseline model, a start-up is more likely based on essential skills if the founder has industry or leadership experience. Thus, the skills which were transferred and which have been essential seem to be skills related to craftsmen work in the first line. Table 11 shows that there is almost no effect on firm outcome when estimating the causal effect of specific skills acquired at a former employer. At least, the transfer of essential skills is associated with a lower probability to shrink and a higher probability to hire one new (possibly the first) employee during the initial business years after formation. This demonstrates that the effect on firm outcome has to be differentiated by the type of transferred knowledge.

Table 11: Causal effect of essential specific skills on employment growth and innovation activities

\begin{tabular}{l|c|ccccc}
\hline & $\begin{array}{c}\text { number of } \\
\text { matched } \\
\text { pairs }\end{array}$ & $\begin{array}{c}\text { specific } \\
\text { skills } \\
\text { essential }\end{array}$ & $\begin{array}{c}\text { associated } \\
\text { controls }\end{array}$ & $\begin{array}{c}\text { difference } \\
\text { in out- } \\
\text { come }\end{array}$ & $\begin{array}{c}\text { standard } \\
\text { error of } \\
\text { difference }\end{array}$ \\
\hline Employment growth (start-up - 2009) & & & & & & \\
Employment growth rate & 848 & 0.162 & 0.157 & 0.005 & 0.015 \\
Birch Index & 843 & 6.227 & 6.449 & -0.222 & 1.049 \\
Number of new employees: $<0$ & 861 & 0.129 & 0.172 & -0.043 & 0.020 & $* *$ \\
Number of new employees: 0 & 861 & 0.287 & 0.281 & 0.006 & 0.026 & $*$ \\
Number of new employees: $>0-1$ & 861 & 0.221 & 0.182 & 0.038 & 0.021 & $*$ \\
Number of new employees: $>1-5$ & 861 & 0.266 & 0.271 & -0.005 & 0.024 & \\
Number of new employees: $>5$ & 861 & 0.098 & 0.094 & 0.003 & 0.016 & \\
\hline Innovation activities 2009 & & & & & & \\
In-house R\&D activities $(0 / 1)$ & 868 & 0.222 & 0.227 & -0.005 & 0.022 & \\
R\&D intensity & 693 & 0.031 & 0.028 & 0.003 & 0.006 \\
World market novelty & 863 & 0.041 & 0.049 & -0.008 & 0.012 \\
Market novelty & 863 & 0.147 & 0.137 & 0.010 & 0.020 \\
Product innovation & 865 & 0.354 & 0.331 & 0.023 & 0.026 \\
Process innovation & 866 & 0.225 & 0.177 & 0.048 & 0.022
\end{tabular}

Note: $* * *, * *, *$ depict significance of the difference in outcome at the $1 \%, 5 \%$ and $10 \%$ level respectively; standard errors of the ATT are calculated according to Abadie and Imbens (2006).

Source: KfW/ZEW Start-Up Panel, authors’ calculation. 


\section{Conclusion}

Start-ups are a way to spread technology and knowledge within an economy. Founders of start-ups may pick up ideas that otherwise would have been neglected and bring them to the market. A group of start-ups which are especially apt to spread technology and knowledge are corporate spinoffs.

In this paper, we focused on German spinoffs founded in the period from 2005 to 2008. In identifying spinoffs we directly draw on the notion of knowledge and technology transfer and defined a start-up to be a corporate spinoff if a new idea that the founder developed during her time as an employee in a private company was essential for setting up the new firm. Whereas previous studies proved that spinoffs exhibit higher survival rates, we examined whether the property to be a spinoff causally affects spinoffs' employment growth rates and post-entry innovation activities. The analysis was conducted applying nearest neighbour propensity score matching.

Our key finding is that the transfer of an essential idea is associated with higher post-entry innovation activities but does not result in higher employment growth. The transferred essential idea works as an input factor for the innovation process and either enables or stimulates subsequent innovation activities. Although descriptive analyses showed that employment growth rates are significantly higher for spinoffs than for non-spinoffs, this difference cannot be traced back to the essential idea but appears to be a result of pre-treatment founder-specific characteristics, e.g. a better endowment with human capital. Consequently, spinoffs seem to be 'think tanks' but they are no 'job machines'. Note, however, that this finding is sensitive to our definition of spinoffs. An outstanding result of our paper is that in order to assess the effect of a transfer of knowledge and technology from an incumbent firm to a newly founded firm, it is important to carefully differentiate between varying types of knowledge and technology transfer. If we had included start-ups based on an idea of great importance into the group of spin-offs, results would indicate that this extended group of start-ups does not only show more comprehensive innovation activities but also exhibits higher employment growth. Obviously, transferred ideas distinguish from each other to the extent they offer growth opportunities to start-ups. This finding might be explained by the fact that essential ideas are more likely highly specialised, customised products that target small niche markets whereas ideas of great importance are more likely to be designed to meet the requirements of the mass market. Essential specific skills acquired by the founder during her work for an incumbent firm do not contribute to superior innovation activities but coheres with to a higher probability to employ one new (possibly the first) employee during the initial business years. In the first line, essential specific skills seem to be competences which serve as a basis for running a handicraft business.

Our study has three major limitations. First, the definition of spinoffs applied in this study was motivated by the literature of the emergence of spinoffs that most frequently refers to the transfer and subsequent commercialisation of innovative products, processes or ideas. Nevertheless, possible transfers from an incubator firm to a spinoff are not restricted to knowledge, technologies and ideas but may 
also encompass, among other things, skilled labour or financial capital. Of course, a transfer of skilled labour and financial capital may also contribute to the positive effect of being a spinoff on innovation activities. However, given the data at hand we are unable to single out the effects of transfers others than ideas and specific skills.

Second, our results may be affected by a survival bias and an omitted variable bias. As discussed in the literature review in section 2, previous studies found that spinoffs exhibit a higher probability of survival than non-spinoffs. Unfortunately, we are unable to determine survival rates of spinoffs and non-spinoffs since firms are categorised as spinoffs and non-spinoffs respectively based on their responses to the survey. Thus, our results are conditional on firms that survived until the survey conducted in $2010 .^{22}$ An omitted variable bias may occur if we do not observe all variables relevant for estimating the probability of being a spinoff. Since propensity score matching assumes selection on observables (conditional independence assumption), an omitted variable would bias our results. As Lechner (1998) pointed out, it is impossible to check the validity of CIA with a statistical test. Thus, an omitted variable bias cannot be ruled out. The tests of the Rosenbaum bounds guide us where we have to be cautious when interpreting our results.

Third, our analysis relates firm-specific and founder-specific characteristics measured at time of startup to post-entry outcome variables covering a time span from the second to the fifth business year. However, young firms experience profound changes in the first years of their existence. The longer the time span, the more difficult it is to argue that firm outcome is directly caused by the property of being a spinoff. Furthermore, from a dynamic perspective the different outcome variables mutually affect each other: A firm may invest in R\&D which possibly results in an innovation output. The latter may improve the firm's competitiveness which eventually leads to higher firm growth. Therefore, future research is required to formulate and estimate a dynamic model of spinoffs' growth and innovation activities.

\footnotetext{
${ }^{22}$ Note, however, that our results are confirmed by firms observed in their second business year, where the survival bias is presumably of minor importance.
} 


\section{References}

Aakvik, A. (2001), Bounding a Matching Estimator: The Case of a Norwegian Training Program, Oxford Bulletin of Economics and Statistics, 63 (1), 115-143.

Abadie, A., and G. Imbens (2006), Large sample properties of matching estimators for average treatment effects, Econometrica, 74 (1), 235-267.

Acs, Z. J., and D. Audretsch (1990), Innovation and small firms, London: The MIT Press.

Agarwal, R., R. Echambadi, A. M. Franco and M. Sarkar (2004), Knowledge Transfer through Inheritance: Spin-Out Generation, Development, and Survival, Academy of Management Journal, 47 (4), 501-522.

Aghion, P., R. Blundell, R. Griffith, P. Howitt and S. Prantl (2006), The Effects of Entry on Incumbent Innovation and Productivity. NBER Working Papers 12027, National Bureau of Economic Research, Cambridge, MA.

Anton, J. J., and D. A. Yao (1995), Start-ups, Spin-offs, and Internal Projects, Journal of Law, Economics, and Organization, 11, 362-378.

Arvanitis, S., and T. Stucki (2012), What Determines the Innovation Capability of Firm Founders?, Industrial and Corporate Change, 21 (4), 1049-1084.

Becker, S. O., and M. Caliendo (2007), Sensitivity Analysis for Average Treatment Effects, The Stata Journal, 7 (1), 71-83.

Bhidé, A. V. (2000), The Origin and Evolution of New Businesses, Oxford, UK: Oxford University Press.

Birch, D. L. (1987), Job creation in America: how our smallest companies put the most people to work, New York, NY: Free Press.

Braun, E., and S. MacDonald (1978), Revolution in Miniature, Cambridge, UK: Cambridge University Press.

Brittain, J. W., and J. Freeman (1986), Entrepreneurship in the semiconductor industry, mimeo.

Buenstorf, G. (2007), Evolution on the Shoulders of Giants: Entrepreneurship and Firm Survival in the German Laser Industry, Review of Industrial Organization, 30, 179-202.

Bureau of the Census (1997), 1992 Economic Census: Characteristics of Business Owners, Washington DC: U.S. Department of Commerce, Economics and Statistics Administration, December 1997, Government Printing Office.

Cabral, L., and Z. Wang (2009), Spin-offs: Theory and Evidence from the Early U.S. Automobile Industry, Working Paper RWP 08-15 (revised version July 2009), The Federal Reserve Bank of Kansas City, Kansas City, MO.

Christensen, C. M. (1993), The Rigid Disk Drive Industry: a History of Commercial and Technological Turbulence, Business History Review, 67, 531-588.

Cooper, A. C. (1985), The Role of Incubator Organizations in the Founding of Growth-Oriented Firms, Journal of Business Venturing, 1 (1), 75-86.

Dahl, M. S., and T. Reichstein (2007), Are You Experienced? Prior Experience and the Survival of New Organizations, Industry and Innovation, 14 (5), 497-511. 
Djokovic, D., and V. Souitaris (2008), Spinouts from Academic Institutions: A Literature Review with Suggestions for Further Research, The Journal of Technology Transfer, 33 (3), 225-247.

Egeln, J., H. Fryges, S. Gottschalk and C. Rammer (2009), Performance von akademischen SpinoffGründungen in Österreich, AStA Wirtschafts- und Sozialstatistisches Archiv, 3 (4), 265-283.

Egeln, J., S. Gottschalk, C. Rammer and A. Spielkamp (2003), Public Research Spin-Offs in Germany. Summary Report, ZEW Dokumentation No. 03-04, Zentrum für Europäische Wirtschaftsforschung, Mannheim.

Eriksson, T., and J. M. Kuhn (2006), Firm Spin-Offs in Denmark 1981.2000 - Patterns of Entry and Exit, International Journal of Industrial Organization, 24, 1021-1040.

European Commission (2010), Organisation of the educational system in Germany 2009/2010, Education, Audiovisual and Culture Executive Agency (EACEA), Brussels.

European Commission (2011), National system overview on education systems in Europe and ongoing reforms: Germany, German Eurydice Units, Brussels.

Franco, A. M., and D. Filson (2006), Spin-Outs: Knowledge Diffusion through Employee Mobility, The Rand Journal of Economics, 37 (4), 841-860.

Frosch, K. H. (2009), Do only new brooms sweep clean? A review on workforce age and innovation, MPIDR Working Paper 2009-005, Max Planck Institute for Demographic Research, Rostock.

Fryges, H., S. Gottschalk and K. Kohn (2010), The KfW/ZEW Start-up Panel: Design and Research Potential, Schmollers Jahrbuch, Journal for Applied Social Science Studies, 130 (1), 117-131.

Garvin, D. A. (1983), Spin-Offs and the New Firm Formation Process, California Management Review, 25 (2), 3-20.

Gompers, P., J. Lerner and D. Scharfstein (2005), Entrepreneurial Spawning: Public Corporations and the Genesis of New Ventures, 1986 to 1999, The Journal of Finance, 60 (2), 577-614.

Goodman, A., and B. Sianesi (2005), Early Education and Children's Outcomes: How Long Do the Impacts Last?, Fiscal Studies, 26 (4), 513-548.

Helfat, C. E., and M. B. Lieberman (2002), The Birth of Capabilities: Market Entry and the Importance of Pre-History, Industrial and Corporate Change, 11 (4), 725-760.

Hyytinen, A., and M. Maliranta (2008), When Do Employees Leave their Job for Entrepreneurship?, Scandinavian Journal of Economics, 110 (1), 1-21.

Klepper, S. (2001), Employee Start-ups in High-Tech Industries, Industrial and Corporate Change, 10 (3), 639-674.

Klepper, S. (2002), The Capabilities of New Firms and the Evolution of the US Automobile Industry, Industrial and Corporate Change, 11 (4), 645-666.

Klepper, S., and P. Thompson (2010), Disagreements and Intra-Industry Spinoffs, International Journal of Industrial Organization, 28, 526-538.

Klepper, S., and S. Sleeper (2005), Entry by Spinoffs, Management Science, 51 (8), 1291-1306.

Lechner, M. (1998), Mikroökonomische Evaluationsstudien: Anmerkungen zu Theorie und Praxis, in: Pfeiffer, F., and W. Pohlmeier (eds.), Qualifikation, Weiterbildung und Arbeitsmarkterfolg, ZEWWirtschaftsanalysen, Vol. 31, Baden-Baden: Nomos, 13-38.

Lechner, M. (1999), Earnings and Employment Effects of Continuous Off-the-Job Training in East Germany after Unification, Journal of Business \& Economic Statistics, 17 (1), 74-90. 
Legler, H., and R. Frietsch (2006), Neuabgrenzung der Wissenswirtschaft - forschungsintensive Industrien und wissensintensive Dienstleistungen (NIW/ISI-Listen 2006), Studien zum deutschen Innovationssystem Nr. 22-2007, Karlsruhe, Hanover.

Lejpras, A., and A. Stephan (2011), Locational conditions, cooperation, and innovativeness: evidence from research and company spin-offs, The Annals of Regional Science, 46, 543-575.

Leuven, E., and B. Sianesi (2003), PSMATCH2: Stata module to perform full Mahalanobis and propensity score matching, common support graphing, and covariate imbalance testing, http://ideas.repec.org/c/boc/bocode/s432001.html.

Muendler, M.-A., J. E. Rauch and O. Tocoian (2012), Employee Spinoffs and Other Entrants: Stylized Facts from Brazil, International Journal of Industrial Organization, 30, 447-458.

OECD (2005), Oslo Manual, Guidelines for Collecting and Interpreting Innovation Data, OECD, Paris.

O’Shea, R., H. Chugh, and T. Allen (2008), Determinants and Consequences of University Spinoff Activity: A Conceptual Framework, The Journal of Technology Transfer, 33 (6), 653-666.

Peters, B. (2009), Persistence of innovation: stylised facts and panel data evidence, Journal of Technology Transfer, 34, 226-243.

Phillips, D. J. (2002), A Genealogical Approach to Organizational Life Chances: The Parent-Progeny Transfer among Silicon Valley Law Firms, 1946-1996, Administrative Science Quarterly, 47, 474-506.

Rauch J. E., and J. Watson (2004), Are There Too Many Entrepeneurs? A Model of Client-Based Entrepreneurship, University of California San Diego, unpublished manuscript.

Rosenbaum, P. R. (2002), Observational Studies, $2^{\text {nd }}$ ed., New York: Springer.

Rosenbaum, P. R., and D. B. Rubin (1983), The Central Role of the Propensity Score in Observational for Causal Effects, Biometrika, 70 (1), 41-55.

Rubin, D. B. (1977), Assignment to Treatment Group on the Basis of a Covariate, Journal of Educational Statistics, 2, 1-26.

Sleeper, S. D. (1998), The Role of Firm Capabilities in the Evolution of the Laser Industry: the Making of a High-tech-Market, Ph.D. dissertation, Carnegie Mellon University, Pittsburgh.

Wiggins, S. N. (1995), Entrepreneurial Enterprises, Endogenous Ownership, and the Limits to Firm Size, Economic Inquiry, 33, 54-69. 


\section{Appendix}

Table 12: Composition of industry sectors

\begin{tabular}{|c|c|c|}
\hline & Sector & NACE Rev. 2 \\
\hline & \multicolumn{2}{|l|}{ High-technology industries } \\
\hline 1 & Cutting-edge technology manufacturing & $\begin{array}{l}20.20,21.10,21,20,24.46,25.40,26.11 \\
26.20,26.30,26.40,26.51,26.60,30.30 \\
30.40,32,50\end{array}$ \\
\hline 2 & High-technology manufacturing & $\begin{array}{l}\text { 20.13, 20.14, 20.16, 20.17, 20.41, 20.51, } \\
\text { 20.53, 20.59, 22.11, 22.19, 23.19, 26.70, } \\
\text { 27.11, 27.12, 27.20, 27.40, 27.90, } \\
\text { 28.11-15, 28.23, 28.24, 28.29, 28.30, } \\
\text { 28.41, 28.49, 28.92-96, 28.99, 29.10, } \\
\text { 29.31, 29.32, 30.20 }\end{array}$ \\
\hline 3 & Technology-intensive services & $\begin{array}{l}\text { 61.1-3, } 62 \text { (without 62.01), 63.1, } \\
71.1-2,72.1\end{array}$ \\
\hline \multirow[t]{2}{*}{4} & Software supply and consultancy & 62.01 \\
\hline & Non-high-tech industries & \\
\hline 5 & Non-high-tech manufacturing & 10-33 (without sectors 1 and 2) \\
\hline 6 & Skill-intensive services (non-technical consulting services) & $69.1-2,70.2,72.2,73.1-2$ \\
\hline 7 & Other business-oriented services & $\begin{array}{l}\text { 49.2, 49.5, 50.2, 50.4, 51.2, 52, 53, 61.9, } \\
\text { 63.9, 64, 74.1, 74.3, 74.9, 77.1, 77.3-4, } \\
78,80-82\end{array}$ \\
\hline 8 & Consumer-oriented services & $\begin{array}{l}\text { 49.1, 49.3-4, 50.1, 50.3, 51.1, 55, 56, } \\
\text { 58-60, 65-66, 68, 74.2, 77.2, 79, 85.5-6, } \\
90-93,95-96\end{array}$ \\
\hline 9 & Construction & $41-43$ \\
\hline 10 & Wholesale and retail trade (without trade agents) & 45-47 (without 46.1) \\
\hline
\end{tabular}

Cutting-edge manufacturing technology: manufacturing industries with average $\mathrm{R} \& \mathrm{D}$ expenditure $>7.0 \%$ of total sales. High-technology manufacturing: manufacturing industries with average R\&D expenditure $2.5-7.0 \%$ of total sales. Source: own classification, classification of high-technology industries based on Legler and Frietsch (2006). 
Table 13: Wording of questions that identify corporate spinoffs

1 Was at least one founder sometime during his working life employed by a private company?

$2 \quad$ In which business unit did the founders work there?

2-1 production/provision of services

2-2 sales

2-3 administration

2-4 research

$2-5$ other

3 I will read out several factors that might have been relevant for the formation of your firm. Please tell me whether these factors were 'essential', 'of great importance', 'of minor importance', or 'of no importance.'

3-1 Specific skills that at least one founder acquired during his work for the private company.

3-2 New ideas of at least one founder that accrued from his research. (interviewer instruction: founders in a research unit only)

3-3 New ideas of at least one founder that accrued from his work/from his work outside research for the private company.

4 Which new ideas that were essential/of great importance for the establishment of your firm were it in concrete?

Source: KfW/ZEW Start-Up Panel. 


\begin{tabular}{|c|c|c|c|}
\hline & spinoffs & non-spinoffs & p-value ${ }^{a}$ \\
\hline Age of the (oldest) entrepreneur at start-up (in years) & 41.41 & 40.90 & 0.352 \\
\hline Entrepreneur’s industry experience at start-up (in years) & 15.19 & 14.79 & 0.453 \\
\hline \multicolumn{4}{|l|}{ Educational degree } \\
\hline $\mathrm{PhD}$ & 0.09 & 0.03 & 0.000 \\
\hline university & 0.32 & 0.21 & 0.000 \\
\hline university of applied sciences & 0.23 & 0.18 & 0.087 \\
\hline university of corporate education & 0.02 & 0.02 & 0.911 \\
\hline commercial college & 0.06 & 0.05 & 0.468 \\
\hline master craftsman & 0.23 & 0.30 & 0.009 \\
\hline vocational training & 0.28 & 0.31 & 0.264 \\
\hline no vocational training & 0.02 & 0.10 & 0.243 \\
\hline \multicolumn{4}{|l|}{ Field of specialisation } \\
\hline natural sciences & 0.22 & 0.19 & 0.196 \\
\hline engineering and technology & 0.53 & 0.57 & 0.128 \\
\hline social sciences & 0.34 & 0.28 & 0.032 \\
\hline humanities & 0.05 & 0.04 & 0.155 \\
\hline Own patents before start-up & 0.05 & 0.02 & 0.000 \\
\hline Female entrepreneur & 0.20 & 0.17 & 0.316 \\
\hline Entrepreneur with migration background & 0.07 & 0.06 & 0.614 \\
\hline Team foundation & 0.43 & 0.26 & 0.000 \\
\hline \multicolumn{4}{|l|}{ Entrepreneur's position at previous employer } \\
\hline executive director & 0.17 & 0.14 & 0.129 \\
\hline executive employee & 0.68 & 0.57 & 0.000 \\
\hline other employee & 0.25 & 0.35 & 0.001 \\
\hline \multicolumn{4}{|l|}{ Entrepreneur's business unit at previous employer } \\
\hline production/provision of services & 0.76 & 0.81 & 0.064 \\
\hline sales & 0.34 & 0.28 & 0.036 \\
\hline administration & 0.22 & 0.18 & 0.147 \\
\hline research & 0.19 & 0.09 & 0.000 \\
\hline Size of previous employer (number of employees) & $9,116.47$ & $5,790.08$ & 0.209 \\
\hline Number of observations & 302 & 2,849 & \\
\hline
\end{tabular}


Table 15: Means of explanatory variables after matching (baseline model)

\begin{tabular}{|c|c|c|c|}
\hline & spinoffs & $\begin{array}{l}\text { control group } \\
\text { of non-spinoffs }\end{array}$ & p-value ${ }^{a}$ \\
\hline Age of the (oldest) entrepreneur at start-up (in years) & 41.22 & 42.06 & 0.265 \\
\hline Entrepreneur's industry experience at start-up (in years) & 17.63 & 18.69 & 0.156 \\
\hline \multicolumn{4}{|l|}{ Educational degree } \\
\hline $\mathrm{PhD}$ & 0.08 & 0.07 & 0.749 \\
\hline university & 0.31 & 0.29 & 0.716 \\
\hline university of applied sciences & 0.23 & 0.18 & 0.178 \\
\hline university of corporate education & 0.02 & 0.02 & 0.779 \\
\hline commercial college & 0.06 & 0.06 & 1.000 \\
\hline master craftsman & 0.23 & 0.22 & 0.617 \\
\hline vocational training & 0.29 & 0.32 & 0.364 \\
\hline no vocational training & 0.02 & 0.04 & 0.101 \\
\hline \multicolumn{4}{|l|}{ Field of specialisation } \\
\hline natural sciences & 0.22 & 0.17 & 0.115 \\
\hline engineering and technology & 0.53 & 0.53 & 1.000 \\
\hline social sciences & 0.33 & 0.33 & 1.000 \\
\hline humanities & 0.05 & 0.04 & 0.554 \\
\hline Own patents before start-up & 0.04 & 0.04 & 1.000 \\
\hline Female entrepreneur & 0.20 & 0.25 & 0.131 \\
\hline Entrepreneur with migration background & 0.06 & 0.06 & 1.000 \\
\hline Team foundation & 0.43 & 0.37 & 0.172 \\
\hline \multicolumn{4}{|l|}{ Entrepreneur's position at previous employer } \\
\hline executive director & 0.17 & 0.20 & 0.389 \\
\hline executive employee & 0.68 & 0.65 & 0.536 \\
\hline other employee & 0.25 & 0.25 & 1.000 \\
\hline \multicolumn{4}{|l|}{ Entrepreneur's business unit at previous employer } \\
\hline production/provision of services & 0.78 & 0.79 & 0.762 \\
\hline sales & 0.33 & 0.37 & 0.293 \\
\hline administration & 0.21 & 0.27 & 0.118 \\
\hline research & 0.17 & 0.17 & 0.911 \\
\hline Size of previous employer (number of employees) & $9,279.63$ & $13,194.95$ & 0.379 \\
\hline Number of observations & 287 & 287 & \\
\hline
\end{tabular}

${ }^{\mathrm{a}}$ Continuous variables: $\mathrm{p}$-value of a t-test for difference in means; indicator variables: Pearson's $\chi^{2}$ test on independence.

Descriptive statistics based on the matched sample with employment growth rate as outcome variable.

Source: KfW/ZEW Start-Up Panel, authors’ calculations. 
Table 16: Fully integrated linear model: Interaction effects

\begin{tabular}{|c|c|c|c|c|c|}
\hline \multirow{2}{*}{$\begin{array}{l}\text { Dependent variable } \\
\text { Age of the (oldest) founder at start-up (ln) }\end{array}$} & $\begin{array}{l}\text { R\&D (0/1) } \\
\text { coeff. }\end{array}$ & \multicolumn{2}{|c|}{$\begin{array}{l}\text { R\&D intensity } \\
\text { coeff. }\end{array}$} & \multicolumn{2}{|c|}{$\begin{array}{l}\text { product } \\
\text { innovation } \\
\text { coeff. }\end{array}$} \\
\hline & -1.976 & -0.760 & & 1.450 & \\
\hline Age of the (oldest) founder at start-up (ln) ${ }^{2}$ & 0.283 & 0.119 & & -0.197 & \\
\hline Founder’s industry experience at start-up (ln) & -0.053 & 0.073 & $*$ & 0.089 & \\
\hline Founder's industry experience at start-up $(\ln )^{2}$ & 0.012 & -0.017 & & -0.024 & \\
\hline \multicolumn{6}{|l|}{ Educational degree } \\
\hline $\mathrm{PhD}$ & 0.083 & 0.057 & & -0.000 & \\
\hline university & -0.081 & 0.001 & & -0.045 & \\
\hline university of applied sciences & -0.047 & -0.035 & & -0.018 & \\
\hline university of corporate education & 0.118 & -0.015 & & 0.414 & $* *$ \\
\hline commercial college & -0.068 & -0.022 & & -0.075 & \\
\hline master craftsman & -0.014 & 0.011 & & 0.066 & \\
\hline vocational training & -0.035 & -0.009 & & -0.126 & \\
\hline no vocational training & 0.296 & 0.388 & $* *$ & -0.137 & \\
\hline \multicolumn{6}{|l|}{ Field of specialisation } \\
\hline natural sciences & 0.069 & 0.028 & & 0.079 & \\
\hline engineering and technology & 0.135 & 0.036 & $*$ & 0.153 & * \\
\hline social sciences & 0.102 & 0.039 & $*$ & 0.053 & \\
\hline humanities & 0.138 & 0.017 & & 0.030 & \\
\hline Own patents before start-up & -0.044 & -0.022 & & 0.068 & \\
\hline Female founder & -0.069 & -0.007 & & -0.040 & \\
\hline Founder with migration background & -0.082 & -0.019 & & 0.125 & \\
\hline Team foundation & -0.016 & -0.010 & & -0.059 & \\
\hline \multicolumn{6}{|l|}{ Founder's position at previous employer } \\
\hline executive director & 0.041 & 0.041 & & 0.086 & \\
\hline executive employee & 0.175 & 0.060 & & 0.081 & \\
\hline other employee & 0.151 & 0.048 & & -0.004 & \\
\hline \multicolumn{6}{|l|}{ Founder's business unit at previous employer } \\
\hline production/provision of services & 0.066 & 0.003 & & 0.092 & \\
\hline sales & 0.035 & 0.012 & & -0.131 & $*$ \\
\hline administration & -0.101 & -0.017 & & 0.036 & \\
\hline research & -0.033 & -0.006 & & 0.163 & $*$ \\
\hline Size of previous employer (ln(number of employees)) & 0.022 & 0.004 & & -0.014 & \\
\hline Size of previous employer $(\ln (\text { number of employees }))^{2}$ & -0.000 & -0.001 & & 0.001 & \\
\hline Number of observations & 3,145 & 2.4 & & 3,13 & \\
\hline $\mathrm{R}^{2}$ & 0.246 & 0.22 & & 0.08 & \\
\hline
\end{tabular}

Note: Baseline model; common support condition applies. ***, **, * depict significance at the $1 \%$, $5 \%$ and $10 \%$ level respectively; additional interactions: dummy variables for industry sector, year of firm formation, firms promoted by KfW.

Source: KfW/ZEW Start-Up Panel, authors’ calculation. 
Table 17: Probit estimation of the probability of being a start-up for which specific skills are essential

\begin{tabular}{|c|c|c|c|}
\hline & marginal effect & $\begin{array}{c}\text { robust standard } \\
\text { error }\end{array}$ & \\
\hline Age of the (oldest) founder at start-up (ln) & 1.355 & 0.933 & \\
\hline Age of the (oldest) founder at start-up (ln) ${ }^{2}$ & -0.178 & 0.128 & \\
\hline Founder's industry experience at start-up (ln) & 0.167 & 0.040 & $* * *$ \\
\hline Founder's industry experience at start-up (ln) ${ }^{2}$ & -0.033 & 0.010 & $* * *$ \\
\hline \multicolumn{4}{|l|}{ Educational degree } \\
\hline $\mathrm{PhD}$ & 0.020 & 0.059 & \\
\hline university & 0.050 & 0.039 & \\
\hline university of applied sciences & 0.023 & 0.037 & \\
\hline university of corporate education & 0.040 & 0.067 & \\
\hline commercial college & 0.094 & 0.052 & * \\
\hline master craftsman & 0.065 & 0.036 & $*$ \\
\hline vocational training & 0.044 & 0.036 & \\
\hline no vocational training & -0.028 & 0.093 & \\
\hline \multicolumn{4}{|l|}{ Field of specialisation } \\
\hline natural sciences & 0.009 & 0.032 & \\
\hline Engineering and technology & -0.020 & 0.029 & \\
\hline social sciences & -0.018 & 0.029 & \\
\hline humanities & -0.043 & 0.047 & \\
\hline Own patents before start-up & -0.037 & 0.062 & \\
\hline Female founder & 0.026 & 0.025 & \\
\hline Founder with migration background & 0.002 & 0.036 & \\
\hline Team foundation & 0.010 & 0.027 & \\
\hline \multicolumn{4}{|l|}{ Founder's position at previous employer } \\
\hline executive director & 0.100 & 0.045 & $* *$ \\
\hline executive employee & 0.113 & 0.040 & $* * *$ \\
\hline other employee & 0.028 & 0.042 & \\
\hline \multicolumn{4}{|l|}{ Founder's business unit at previous employer } \\
\hline production/provision of services & 0.043 & 0.024 & $*$ \\
\hline sales & 0.039 & 0.022 & $*$ \\
\hline administration & 0.009 & 0.024 & \\
\hline research & -0.029 & 0.031 & \\
\hline Size of previous employer (ln(number of employees)) & -0.013 & 0.011 & \\
\hline Size of previous employer $\left(\ln (\text { number of employees) })^{2}\right.$ & 0.001 & 0.001 & \\
\hline \multicolumn{4}{|l|}{ Industry (ref. wholesale and retail trade) } \\
\hline cutting-edge technology manufacturing & -0.010 & 0.047 & \\
\hline high-tech manufacturing & 0.018 & 0.053 & \\
\hline technology-intensive services & 0.051 & 0.034 & \\
\hline software supply and consultancy & 0.067 & 0.047 & \\
\hline non-high-tech manufacturing & 0.013 & 0.036 & \\
\hline skill-intensive services & 0.083 & 0.045 & $*$ \\
\hline other business-oriented services & 0.006 & 0.051 & \\
\hline consumer-oriented services & 0.009 & 0.037 & \\
\hline construction & -0.020 & 0.036 & \\
\hline \multicolumn{4}{|l|}{ Year of firm formation (ref. 2005) } \\
\hline 2006 & -0.030 & 0.024 & \\
\hline 2007 & -0.007 & 0.024 & \\
\hline 2008 & 0.024 & 0.027 & \\
\hline Number of observations & & 2,862 & \\
\hline Log pseudolikelihood & & -1699.739 & \\
\hline McFadden's $\mathrm{R}^{2}$ & & 0.032 & \\
\hline
\end{tabular}

$* * *, * *, *$ depict significance at the $1 \%, 5 \%$ and $10 \%$ level respectively and correspond to the test of the underlying coefficient being zero. Additional control variable indicating firms promoted by KfW included.

Source: KfW/ZEW Start-Up Panel, authors’ calculation. 


\section{Technical Appendix}

The Conditional Independence Assumption (CIA, also referred to as unconfoundedness or selection on observables assumption) is essential for the validity of propensity score matching and the interpretation of the estimated ATT. Unfortunately, the CIA cannot be proven or falsified by means of a statistical test (Lechner, 1998). However, it is possible to estimate how sensitive the ATT is with respect to deviations from the CIA. We conduct Mantel-Haenszel tests of the Rosenbaum bounds as described in Aakvik (2001) and Becker and Caliendo (2007). The tests indicate how strongly an unobserved variable must affect the selection into the treatment so that the estimated ATT vanishes. The presentation of the methodology closely follows Becker and Caliendo (2007).

Let assume that the probability that firm $i$ is a spinoff is given by

$$
P_{i}=P\left(\text { spinoff }=1 \mid x_{i}, u_{i}\right)=F\left(x_{i}^{\prime} \beta+\gamma u_{i}\right) .
$$

As before, $x_{i}$ is a vector of observable covariates. $u_{i}$ is an unobservable variable which, for simplicity, is assumed to be binary, $u_{i} \in\{0,1\}$. Further, it is assumed that $F$ is the logistic distribution. If the coefficient $\gamma$ is zero, the unobserved variable $u_{i}$ does not affect the probability of being a spinoff and there is no hidden selection bias.

For a matched pair of firms $i$ and $j$, Rosenbaum (2002) showed that the odds ratio that either of the two firms is a spinoff is bounded in the following way:

$$
\frac{1}{e^{\gamma}} \leq \frac{P_{i}\left(1-P_{j}\right)}{P_{j}\left(1-P_{i}\right)} \leq e^{\gamma}
$$

Only in the case of no hidden bias $\left(\gamma=0\right.$ and $\left.e^{\gamma}=1\right)$, do the two firms $i$ and $j$ have the same probability of being a spinoff as implied by propensity score matching. If the unobserved factor $u_{i}$ has an impact on the probability of being a spinoff ( $\gamma>0$ and $e^{\gamma}>1$ ), the Rosenbaum bounds drift apart.

Aakvik (2001) suggest using the Mantel-Haenszel test statistics to test the null hypothesis of no treatment effect. For a fixed hidden bias $e^{\gamma} \geq 1$ and $u_{i} \in\{0,1\}$, the Mantel-Haenszel test statistics is bounded by two known distributions (Rosenbaum, 2002). $Q_{M H}^{+}$denotes the bound of the MantelHaenszel test statistics, assuming that the treatment effect was overestimated. That is, for a positive (negative) treatment effect we test whether the smallest (highest) possible value of the treatment effect given $e^{\gamma}$ is still significant. Accordingly, $Q_{M H}^{-}$denotes the bound of the Mantel-Haenszel test statistics, assuming that treatment effect was underestimated.

Table 18 shows the Mantel-Haenszel test statistics and the associated significance levels for all outcome variables for which we found a significant ATT in the baseline model. ${ }^{23}$ The test statistics are reported both under the assumption of overestimation and underestimation of the ATT. The first col-

\footnotetext{
${ }^{23}$ The tests were computed using the Stata programme mhbounds (Becker and Caliendo, 2007).
} 
umn of Table 18 shows the fixed value of $e^{\gamma}$ in a range from 1.00 to $1.50 .{ }^{24}$ If $e^{\gamma}=1.00$ there is no hidden bias and the test statistics $Q_{M H}^{+}$and $Q_{M H}^{-}$coincide. Since we only found positive effects of being a spinoff on the outcome variables in Table 18, the test statistics under the assumption of underestimation of the ATT are always significant: The effects were positive without a hidden bias and they remain positive in case we underestimated these effects.

Assuming an overestimation of the treatment effect, the ATT of being a spinoff on R\&D activities nevertheless remains significant over the whole range of $e^{\gamma} .{ }^{25}$ Thus, the test results confirm a positive treatment effect on $R \& D$ activities even if we assume that an unobserved variable causes a 'strong' positive selection bias. The effect on the probability to introduce a product (process) innovation vanishes for a 'strong' positive selection bias but is still positive at the $10 \%$ significance level for a 'moderate' selection bias with $e^{\gamma}=1.25\left(e^{\gamma}=1.20\right)$. The effect on the probability to introduce a market novelty remains significant at the $10 \%$ significance level for a 'weak' selection bias only $\left(e^{\gamma}=1.10\right)$. A 'moderate' or 'strong' selection bias drives this effect down to zero.

These results are, however, worst-case scenarios. The tests do not prove that an unobserved variable exists. Likewise, they do not prove that in truth there is no effect of a transferred essential idea on the probability to introduce a market novelty. Nevertheless, the tests guide us to be cautious when interpreting our results. They show that the effect of being a spinoff on the probability to introduce a market novelty is not robust if a confounding factor exists. On the other hand, being a spinoff is positively related to post-entry R\&D activities even in the presence of a 'strong' confounding factor.

\footnotetext{
${ }^{24}$ There is no a priori rule for the choice of the range of $e^{\gamma}$. In our case, the chosen range from 1.00 to 1.50 is sufficient to demonstrate the effect of a potential unobserved variable. If $e^{\gamma}=1.50$, firms that are identical in their observable characteristics in $x_{i}$, could differ in their odds of being a spinoff by a factor of 1.50. For example, if the treated firm $i$ has an estimated probability of being a spinoff or 0.70 , the probability of the matched non-treated firm $j$ could be as low as 0.61 .

${ }^{25}$ The test in the form applied in this paper requires binary outcome variables. We therefore used a binary transformation of the variable R\&D intensity. The resulting dummy variable takes the value one if the R\&D intensity is larger than or equal to the mean of $R \& D$ intensity and zero otherwise.
} 
Table 18: Mantel-Haenszel test of Rosenbaum bounds (baseline model)

\begin{tabular}{|c|c|c|c|c|c|c|c|c|c|c|c|c|c|c|c|c|c|c|c|c|}
\hline \multirow[b]{2}{*}{$e^{\gamma}$} & \multicolumn{4}{|c|}{ in-house R\&D activities (0/1) } & \multicolumn{4}{|c|}{ R\&D intensity ${ }^{a}$} & \multicolumn{4}{|c|}{ market novelty } & \multicolumn{4}{|c|}{ product innovation } & \multicolumn{4}{|c|}{ process innovation } \\
\hline & $Q_{M H}^{+}$ & $Q_{M H}^{-}$ & $p_{M H}^{+}$ & $p_{M H}^{-}$ & $Q_{M H}^{+}$ & $Q_{\bar{M} H}^{-}$ & $p_{M H}^{+}$ & $p_{\bar{M} H}^{-}$ & $Q_{M H}^{+}$ & $Q_{M H}^{-}$ & $p_{M H}^{+}$ & $p_{M H}^{-}$ & $Q_{M H}^{+}$ & $Q_{\bar{M} H}^{-}$ & $p_{M H}^{+}$ & $p_{\bar{M} H}^{-}$ & $Q_{M H}^{+}$ & $Q_{\bar{M} H}^{-}$ & $p_{M H}^{+}$ & $p_{\bar{M} H}^{-}$ \\
\hline 1.00 & 4.050 & 4.050 & 0.000 & 0.000 & 3.413 & 3.413 & 0.000 & 0.000 & 1.932 & 1.932 & 0.027 & 0.027 & 2.746 & 2.746 & 0.003 & 0.003 & 2.407 & 2.407 & 0.008 & 0.008 \\
\hline 1.05 & 3.781 & 4.327 & 0.000 & 0.000 & 3.205 & 3.629 & 0.001 & 0.000 & 1.699 & 2.169 & 0.045 & 0.015 & 2.462 & 3.035 & 0.007 & 0.001 & 2.155 & 2.665 & 0.016 & 0.004 \\
\hline 1.10 & 3.522 & 4.588 & 0.000 & 0.000 & 3.004 & 3.833 & 0.001 & 0.000 & 1.476 & 2.394 & 0.070 & 0.008 & 2.190 & 3.308 & 0.014 & 0.000 & 1.912 & 2.909 & 0.028 & 0.002 \\
\hline 1.15 & 3.275 & 4.839 & 0.001 & 0.000 & 2.812 & 4.029 & 0.002 & 0.000 & 1.263 & 2.609 & 0.103 & 0.005 & 1.930 & 3.570 & 0.027 & 0.000 & 1.681 & 3.143 & 0.046 & 0.001 \\
\hline 1.20 & 3.039 & 5.079 & 0.001 & 0.000 & 2.629 & 4.217 & 0.004 & 0.000 & 1.060 & 2.816 & 0.145 & 0.002 & 1.681 & 3.821 & 0.046 & 0.000 & 1.460 & 3.367 & 0.072 & 0.000 \\
\hline 1.25 & 2.813 & 5.311 & 0.002 & 0.000 & 2.455 & 4.398 & 0.007 & 0.000 & 0.865 & 3.015 & 0.194 & 0.001 & 1.443 & 4.062 & 0.075 & 0.000 & 1.248 & 3.583 & 0.106 & 0.000 \\
\hline 1.30 & 2.597 & 5.534 & 0.005 & 0.000 & 2.287 & 4.573 & 0.011 & 0.000 & 0.677 & 3.207 & 0.249 & 0.001 & 1.214 & 4.295 & 0.112 & 0.000 & 1.044 & 3.792 & 0.148 & 0.000 \\
\hline 1.35 & 2.389 & 5.749 & 0.008 & 0.000 & 2.126 & 4.742 & 0.017 & 0.000 & 0.497 & 3.392 & 0.309 & 0.000 & 0.994 & 4.519 & 0.160 & 0.000 & 0.849 & 3.992 & 0.198 & 0.000 \\
\hline 1.40 & 2.188 & 5.957 & 0.014 & 0.000 & 1.972 & 4.906 & 0.024 & 0.000 & 0.324 & 3.571 & 0.373 & 0.000 & 0.782 & 4.735 & 0.217 & 0.000 & 0.661 & 4.186 & 0.254 & 0.000 \\
\hline 1.45 & 1.995 & 6.159 & 0.023 & 0.000 & 1.823 & 5.065 & 0.034 & 0.000 & 0.157 & 3.744 & 0.438 & 0.000 & 0.578 & 4.944 & 0.282 & 0.000 & 0.479 & 4.374 & 0.316 & 0.000 \\
\hline 1.50 & 1.809 & 6.354 & 0.035 & 0.000 & 1.679 & 5.219 & 0.047 & 0.000 & -0.005 & 3.912 & 0.502 & 0.000 & 0.380 & 5.146 & 0.352 & 0.000 & 0.304 & 4.556 & 0.381 & 0.000 \\
\hline
\end{tabular}

${ }^{\mathrm{a}}$ Binary transformation of R\&D intensity, taking the value one if the R\&D intensity is larger than or equal to the mean of R\&D intensity and zero otherwise.

$e^{\gamma} \quad$ odds of differential assignment due to unobserved factors

$Q_{M H}^{+} \quad$ Mantel-Haenszel statistic (assumption: overestimation of treatment effect)

$Q_{M H}^{-} \quad$ Mantel-Haenszel statistic (assumption: underestimation of treatment effect)

$p_{M H}^{+} \quad$ significance level (assumption: overestimation of treatment effect)

$p_{M H}^{-} \quad$ significance level (assumption: underestimation of treatment effect)

Source: KfW/ZEW Start-Up Panel, authors’ calculation. 